\title{
Review: Advances in the methodology and application of tracing in karst aquifers
}

\author{
Ralf Benischke $^{1}$
}

Received: 31 May 2020 / Accepted: 22 November 2020 / Published online: 20 January 2021

(C) The Author(s) 2021

\begin{abstract}
Tracer methods have been widely used in many fields of environmental and natural sciences, and also in human health sciences. In particular, tracers are used in the study of karst hydrogeology, typically focusing on phenomena such as sinkholes, sinking rivers and large karst springs. It is known that tracers have been used since antiquity. The aim of tracer tests has been to investigate underground flow paths, transport processes and water-rock interactions, and to get an insight into the functioning of a karst aquifer. In karst hydrogeology, tracer methods are the most important investigation tools beside conventional hydrological methods. In early times, tracer methods were applied only to investigate underground flow-paths. Later they were also used to elucidate transport processes associated with water flow, and today they are often the basis, together with detailed hydrological information, of groundwater protection investigations and aquifer modelling. Many substances (spores, microspheres, bacteriophages, salt tracers, fluorescent dyes, radioactive substances) have been investigated for their properties and potential usage in environmental investigations, in particular the often unknown and inaccessible underground systems of karst areas. A great number of analytical techniques is available. This includes instrumentation for laboratory applications and direct online, on-site or in-situ field measurements. Modern instruments have a high capability for data acquisition, storage and transmission in short intervals, as a basis for quantitative evaluation and modelling. This enables research on the hydrological and hydrochemical dynamics of aquifers and their response to different natural or anthropogenic impacts.
\end{abstract}

Keywords Karst · General hydrogeology $\cdot$ Tracer tests

\section{Introduction}

Tracer techniques are well known in hydrogeology as specialized methods to investigate flow-paths, flow and transport processes, and water-rock interactions, as well as to solve practical problems in environmental sciences in general. Tracers are used in many fields of natural and technical sciences, and even in human medicine. They can be distinguished between natural and artificial (applied) tracers. The term "tracer" can also be used for physico-chemical properties (e.g. heat, electrical conductivity).

Published in the special issue "Five decades of advances in karst hydrogeology"

Ralf Benischke

ralf.benischke@tugraz.at

1 Institute of Applied Geosciences, c/o Graz University of Technology, Rechbauerstrasse 12, A-8010 Graz, Austria
A tracer is a substance or property which can be distinguished unambiguously from other substances or properties in a way that allows one to characterise the investigated system itself or processes therein. A natural tracer occurs in the environment without any intervention by an investigator, and an artificial tracer will be introduced intentionally into a system under study. Natural and artificial tracers can be conservative (ideal) or nonconservative (reactive). Conservative tracers do not undergo chemical or physical changes, adsorption, decay or degradation by water-rock interactions or interactions in biological processes. Nonconservative tracers react with other substances or change, decay or degrade during their transport through a system. In the strictest sense, conservative tracers do not exist, but various substances can be characterised as conservative to a certain degree under specific circumstances. For instance, in karstic conduit flow the fluorescent dye fluorescein sodium can behave like a conservative tracer. Its transport behaviour will be nearly identical to the water molecule itself. The isotopes ${ }^{18} \mathrm{O},{ }^{17} \mathrm{O},{ }^{2} \mathrm{H}$ and ${ }^{3} \mathrm{H}$, constituting the water molecule beside ${ }^{1} \mathrm{H}$ and ${ }^{16} \mathrm{O}$, are also 
conservative tracers, as they do not change the chemical behaviour of the molecule. However, field tests have shown that the isotopes of the water molecule can be transported completely differently to other so-called conservative tracers (e.g. Bromide), as these isotopes show higher diffusivity and characterise the totally transported water volume, whereas the other tracers characterise only a part of it (Behrens 1986). Other substances were accidentally released into the environment and now take part in different transport processes within the water cycle as natural tracers-an example is the release of tritium after atmospheric nuclear tests in the 1960s (Mook 2000).

The main aims of using tracers are the investigation of interconnections between two or more locations in the field, time-of-travel and residence time studies, discharge measurements, research on transport, mixing and circulation processes, water-rock interaction studies, characterisation of aquifer parameters and much more; moreover, successful tracer tests can be conclusive in administrative and court procedures. In many countries, regulations exist for performing a tracer test-for a detailed overview refer to Wolkersdorfer and LeBlanc (2012).

The development of tracer methods has a long tradition and dates back to the classical antiquity. In the following centuries many natural and artificial tracers were used to investigate the complex drainage system of karst aquifers and to understand the various flow and transport processes of matter in such systems. For historical notes on the development of tracer methods with additional references, refer to the electronic supplementary material (ESM).

The methods in hydrogeology, especially in karst hydrogeology, for artificial tracing are described in several textbooks. Examples are Davis et al. (1980, 1985), with partly opposing discussion by Evans (1980), Davis (1980, 1986), Quinlan (1986a, b), Gaspar (1987), and comprehensively in Käss $(1998,2004)$ and Leibundgut et al. (2009), and in book chapters (Benischke et al. 2007; Leibundgut and Seibert 2011), booklets (Wilson et al. 1986; Mull et al. 1988), guidelines (Parriaux et al. 1988; Ward et al. 1998; Schudel et al. 2002; DVGW 2005; OeWAV 2007; Stöckl et al. 2017), national and international standards (e.g. ISO 9555-3 1992; 9555-4 1992) and in a number of review and overview articles (Davis et al. 1980; Flury and Wai 2003; Goldscheider et al. 2008; Abbott et al. 2016), as well as in theses (e.g. Reid 1981) and lecture notes of university courses or of professional associations (e.g. Aley and Fletcher 1976; Aley and Beeman 2015).

This review attempts to give a short overview on currently used methods and technology, and some newer developments, but cannot replace a thorough and detailed study of individual subaspects of the subject. Here, the discussion restricts to hydrogeology of karst and karst aquifers with the focus on artificial tracers, although the fields of tracer application are much more wide-spread.

\section{Natural tracers}

Substances naturally occurring in the water cycle and therefore occurring in all types of aquifers are the numerous inorganic and organic chemical compounds and stable or radioactive isotopes in their various aggregate states. As natural tracers they are also a topic associated to various monitoring techniques (Goldscheider and Drew 2007; Kresic and Stevanovic 2009). One such substance, now a quasi-natural tracer, is tritium $\left({ }^{3} \mathrm{H}\right)$. It was produced in excess above the natural background by atmospheric nuclear tests, and became a powerful tracer for residence time studies in various types of aquifers. After the contractual ban of such nuclear tests, the tritium content in the atmosphere and in the water cycle decreased over decades to a level which is today close to the natural background. Due to the low tritium concentration today, the focus is more and more on the relationship between tritium $\left({ }^{3} \mathrm{H}\right)$ and its daughter product helium $\left({ }^{3} \mathrm{He}\right)$. Stable environmental isotopes such as ${ }^{18} \mathrm{O}$ and deuterium $\left({ }^{2} \mathrm{H}\right)$ are used as natural tracers too, although tritium and deuterium are applied also as artificial tracers. The wide field of applications of natural isotopic tracers comprises studies of recharge processes, dating of groundwater, residence time and water balance studies, and much more, but would exceed the framework of this article. Isotopes and their applications in environmental sciences are comprehensively described in Moser and Rauert (1980), Clark and Fritz (1997), Kendall and McDonnell (2006), Ferronsky and Polyakov (2012), and in the six-volume collection of Mook (2000). With the availability of modern cavity ring-down laser spectrometers for the measurement of the stable isotopes ${ }^{18} \mathrm{O},{ }^{17} \mathrm{O}$ and ${ }^{2} \mathrm{H}$, on-site and online measurements became possible. The first on-site and online application of continuous monitoring the dynamics of stable isotopes ${ }^{18} \mathrm{O}$ and ${ }^{2} \mathrm{H}$ in karst water could be demonstrated at the main water supply for Vienna, a karst spring in the Northern Calcareous Alps in Austria. The measured data (acquisition interval was about $10 \mathrm{~min}$ ) were transmitted via satellite to an evaluation center. Together with short-term discharge data, and data for electrical conductivity and water temperature, it was possible to characterise in detail the quick response of this spring on snow-melt and rainfall-runoff events (Leis et al. 2010, 2011).

An interesting new approach is the investigation of organic carbon as a natural tracer for infiltration processes in karst aquifers, considering the biogeochemical kinetics of nitrogen with respect to organic carbon (Mudarra et al. 2014). In an earlier investigation at the Vaucluse karst spring and some other karst springs of the same area (southeastern France), Emblanch et al. (1998) showed that variations of dissolved organic carbon (DOC) can be attributed to the different infiltration processes during low and high flow periods. It also shows variations during low flow when discharge variations cannot be observed. Additionally, Batiot et al. (2003) 
concluded from a study in the Nerja Cave (southern Spain) that total organic carbon (TOC) can be used as a sensitive natural tracer of infiltration processes. Blondel et al. (2012) estimated at the Vaucluse spring, from fluorescence variations of organic matter, transit times of infiltration water using the excitation-emission-matrix (EEM) fluorescence spectra. A multi-parameter study at alpine karst springs in the western part of Austria investigated the transport dynamics of organic matter, faecal bacteria, and particulate matter with use of EEM-fluorescence spectra. It showed a correlation of organic carbon with humic- and protein-like fluorescence as well as transport of particles correlated with coliform bacteria (Frank et al. 2018).

The relationship between trace metal $(\mathrm{Cu}, \mathrm{Ni})$ transport and natural organic matter (NOM) was investigated in speleothem dripwaters, concluding that trace metal binding varies during colloid and particle transport at low and high flow conditions (Hartland et al. 2012).

Other approaches use the natural microbiological community in water to identify possible sources of pollution. Bacteria are usually (but not exclusively) transported by natural processes into a karst system, e.g. as input of animal excreta from meadows through the topsoil via epikarst into the deeper underground or directly into ponors (Farnleitner et al. 2005, 2010; Reischer et al. 2008; Ryzinska-Paier et al. 2014). Such a source tracking method has the potential of high selectivity and can distinguish between different input locations of alpine farming in a massif. From a monitoring point of view, such bacterial communities can be seen as natural tracers (Pronk et al. 2006, 2009).

\section{Artificial tracers}

Artificial tracers comprise particle, microbial, inorganic and organic chemical tracers (mainly salt tracers and fluorescent dyes), stable isotopes, activated and radioactive tracers. To design a test properly, it should be clear what tracer is suitable for the intended purpose or not. Even common hydrologic tracers are not applicable in every case (e.g. fluorescein sodium in soil experiments, or sodium chloride which is subject to ion-exchange effects).

\section{Particle tracers and microbial tracers}

The advantage of particle tracers in general would be the detection limit of one single particle, which could be at the same time also the disadvantage, as contamination or natural occurrence or erroneous evaluation (and over-interpretation) can happen. Most of the particle tracers are not suitable for hydrological studies due to their transport behaviour (e.g. size, density effects) in water. Even in large-volume conduits with high flow velocity, they can be retained in siphons. Another problem can arise from sorption on sediments. More successful tests have been made with spores and microspheres. Examinations were done on spores of club moss (Lycopodium clavatum) discovered in meltwater from glaciers in the Northern Calcareous Alps in Austria, which seemed to be suitable as a tracer (Mayr 1953, 1954), but with a single type of spore, the water of only one sinkhole (ponor) could be labelled. From an idea of the Slovenian caver France Bar, hydrogeologists and a chemist from Austria developed a new colouring technique for spores (Dechant et al. 1958). Another problem was adsorption to sediments, retention and filtering-out of spores during passage through sediments at low flow velocities. Several large-scale tracer tests in the Austrian Alps (at first in 1956 in the Dachstein massif, later in 1961 in Totes Gebirge) were performed with differently coloured spores, which made it possible to inject a number of tracers within a short time at different places (multi-tracer test) under the same hydrological conditions. The results showed in many cases a radially divergent flow in the karst aquifer. This was interpreted as a large, unique, continuous and slightly updomed body of karst water draining to the karst springs around the karst massif (Zötl 1957a, b; Bauer et al. 1959). In the 1980s, the Dachstein experiments in the Northern Calcareous Alps were repeated under similar hydrologic boundary conditions with the injection of fluorescent dye tracers in some of the same sinkholes or near the older sinkholes (Bauer 1989; Völkl and Eybl 2019). The results showed a largely different drainage pattern, not a divergent flow but a more convergent drainage to the springs, obviously strongly bound to the local tectonic pattern of the massif (Fig. 1).

A thorough reinvestigation of the older test design and the boundary conditions showed that probable contamination from the repeated use of plankton nets, or during preparatory work, or overinterpretation of the detection of one single spore, especially when using uncoloured spores, was the reason for misinterpretation of parts of the drainage pattern. The conclusion is that the use of spores has some inherent difficulties which have to be observed very carefully when using them for a test. Results with one single spore (coloured or uncoloured) or only episodically detected should not be taken as proof. Only a plausible time-series of positive samples or a clear breakthrough curve (BTC) should be interpreted, and should be a guideline for all tracers.

Colouring spores with fluorescent dyes (Käss 1982; Käss and Reichert 1988) made the spore detection and identification easier, but remained labor-intensive. An automatic sampler for outdoor use and an automatic counting technique was tested by Dechant (1996), but not developed further. The spore technique can still be used when observing all the methodological precautionary measures, but as a tracer technique, it plays no role in karst hydrogeology today. 

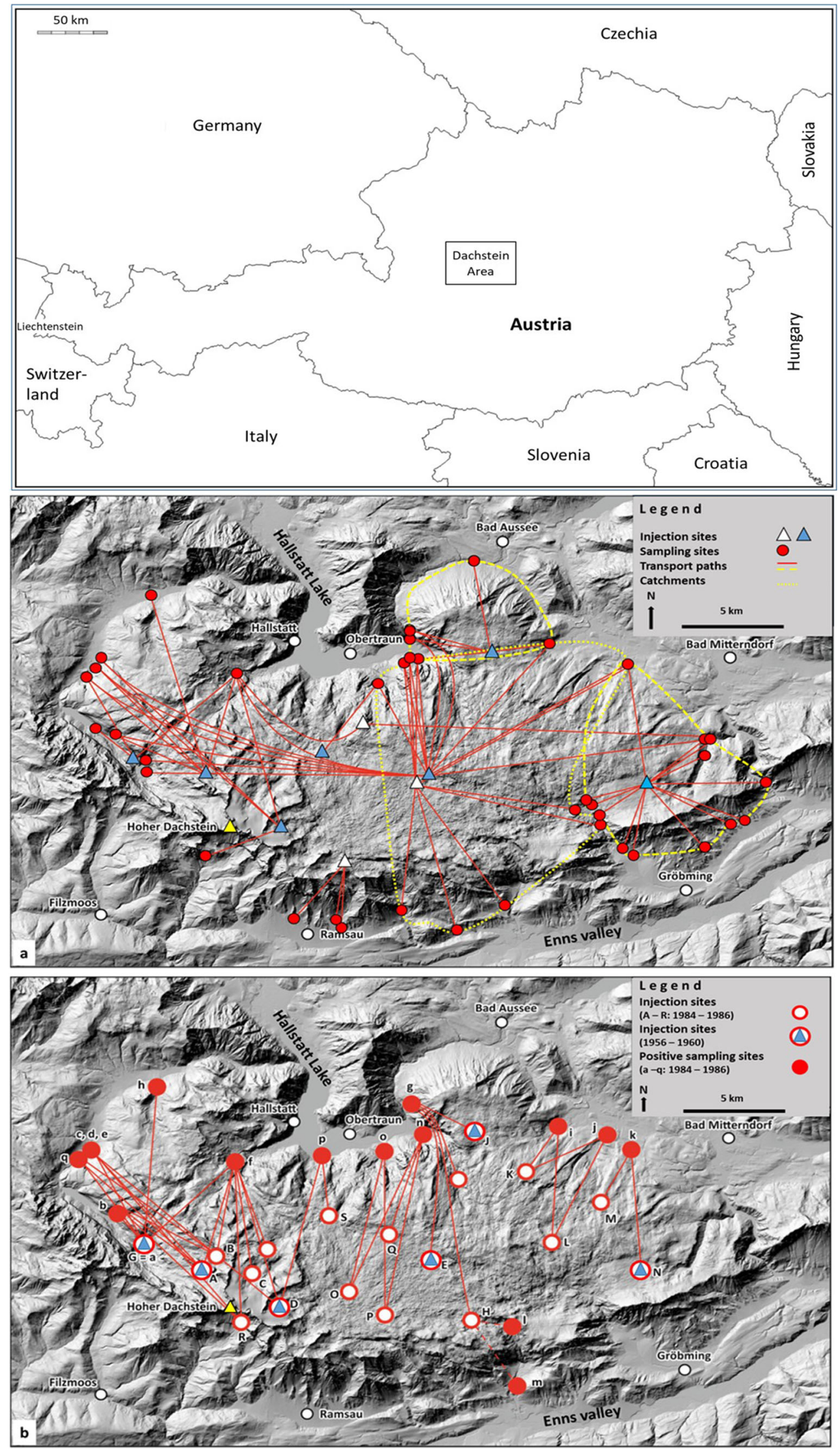
Fig. 1 Tracer tests in the Dachstein Massif (Northern Calcareous Alps, Austria). Top: Country map with position of the study area within Austria. Yellow triangle: Dachstein summit. a Radially divergent drainage inferred from tracer tests (1956-1960) with spores. b Predominantly convergent drainage from tracer tests (1984-1986) with fluorescent dyes. Circles with white center are injection points during 1984-1986 only, circles with blue triangle are injection points during 1956-1960 and 1984-1986. Modified from Schubert (2017) and Legerer P et al. (Geological Survey of Austria), unpublished report: Project "Geologische und Hydrogeologische Zusatzinformationen zum eHYD - 2017" [Additional geologic and hydrogeologic information for eHYD - 2017], 2017

Further progress was made when synthetic microspheres became available, which were developed for use in pharmacy and medicine for diagnostics, as a carrier of drugs or for blood circulation studies. Today a wide variety of microspheres (e.g. Polysciences Inc.) are available in different sizes and structures, as well as with different physical and transport properties. Not all of them are suitable for hydrologic purposes, as some types will be filtered out, some will be adsorbed or degrade during transport. A great advantage is that they can be produced with different (also fluorescent) colours and with different uniform narrow-band grain sizes. Their diameter is commonly $0.05-100 \mu \mathrm{m}$, sometimes larger. They can be sampled by an ordinary water sample (manually or automatically), and it is also possible to use an automatized detection technology such as flow-through cytometry (Niehren and Kinzelbach 1998; Kennedy et al. 2001; Goeppert and Hötzl 2010). Goeppert and Goldscheider (2008) compared the transport properties of two types of microspheres together with uranine under low- and high-flow conditions in a karst aquifer in the high-alpine region of the Austrian-German Alps. Schiperski et al. (2016) investigated, in a karst aquifer of the Swabian Alb (Germany) in multitracer studies, processes that influence the transport and attenuation of particles with different size, density and surface properties compared to uranine.

In many cases tracer tests will be carried out in water protection studies, or studies to trace the fate of contaminants in the groundwater of porous aquifers as well as in karst water. Up to the first half of the twentieth century, supply with clean and potable tap water was not always standard, and is even today not standard in many countries on earth. It is clear that general hygiene together with a safe water supply is a crucial factor with regard to public health. Microbiological methods are of great importance for hygienic assessments. The use of nonpathogenic bacteria and bacteriophages as a surrogate for harmful species brought new insights into the transport behaviour and the fate of bacteria and viruses in water and in different types of aquifers (e.g. Keswick et al. 1982; Hötzl et al. 1991; Harvey 1997; Rossi et al. 1998; Cronin and Pedley 2002).

Another more recent application is the use of so-called DNA tracers, which have a high specificity and high sensitivity. Similar to the other tracers, they are capable of being used as a multipoint tracer (Sabir et al. 2000; Liao et al. 2018), theoretically with almost no limitation on the number of combinations of different DNA species. The only limitation would be the unambiguous detection and identification of the used DNA tracer. Dahlke et al. (2015) provided an overview on the application of synthetic DNA tracers, mainly for the investigation of glacial flow pathways, but provided significant information about their general use, which is worth considering for application in karstic aquifers.

An interesting new approach is the use of natural sediments as artificial tracers. Results from a field tracer test together with uranine in a karst area in western Austria showed comparable BTCs and similar recovery. The detection of sediment particles of 32 different grain-size classes was performed with a mobile particle counter (Goeppert and Goldscheider 2019).

\section{Fluorescent tracers}

For hydrologic tracer tests, various fluorescent dyes became of interest, whereas other tracers exhibiting phosphorescence are currently only used for specially doped microspheres used in flow velocimetry (Kemp et al. 2010). The most prominent fluorescent tracer, which was used for the longest time, is the sodium salt of fluorescein (uranine, also known as fluorescein sodium or often simply but misleading fluorescein). The visual detection of dyes is only one possibility, but is very subjective. With this method it is not possible to detect a dye tracer at high dilution. The development from simple colorimetric techniques to spectrometric techniques offered great advantages and new possibilities. Visible colouring of drinking water during a test, which could not be avoided in every case, was problematic (and still is) and for water-users (people) and the authorities. This led to the search for invisible fluorescent dye tracers. Especially, tracers with emission wavelengths in the UV-region (e.g. sodium naphthionate, amino $\mathrm{G}$ acid, tinopal or other optical brighteners) offered new possibilities for applications in tests where a water supply could be affected (Leibundgut and Wernli 1986; Wernli 1986; Goldscheider et al. 2003; Meus et al. 2014). Hydrological tracers with emission wavelengths at the red end of the visible spectrum or in the near-infrared have not been investigated so far, although compounds synthesized from fluorescein exhibit emission wavelengths at about $700 \mathrm{~nm}$ (Yang et al. 2008). It would be interesting to search for such novel fluorescent dyes which can be used in hydrogeology.

Beside the well-known classical dyes, some new dyes were developed in the past decades and field-tested (Hadi et al. 1997; Einsiedl et al. 1998, 2000; Einsiedl 2000; Einsiedl and Maloszewski 2005), but were applied rarely. There are many other fluorescent substances which could be used for tracing, but costs of production, availability, toxicologial and environmental aspects will restrict their application. 
Most of the dye tracers are listed in the Colour Index (CI) published by the Society of Dyers and Colourists (SDC) in the UK and the American Association of Textile Chemists and Colourists (AATCC). The substances have a unique CI generic name, but not all of them also a CI constitution number. A recent book (Sabnis 2015) about 150 fluorescent dyes comprehensively informs about their chemical and physical as well as toxicological aspects and applications, but is focussed on biochemical and biomedical aspects and only to a minor extent on hydrologic applications. There is a vast number of names for commercially available dyes, which vary in purity and in the type of the delivered matter (as a solution or as a powder).

The suitability of a dye tracer (but also of tracers in general) depends on the intended purpose and the hydrogeological framework including the expected physico-chemical conditions and possible water-rock interactions or the microbiological conditions. In Table 1 the most common dye tracers are summarized with their main properties.

\section{Inorganic salt tracers}

Inorganics comprise the various salt tracers with their cationic and anionic compounds in solution. Their application depends on the chemical and physical properties with respect to the geological environment, and of course, the availability and the costs. Ordinary rock salt (mainly sodium chloride) was used for most tests in the early stages of tracer usage. In tests with salt tracers (Table 2), in particular for long-distance tests, a huge amount was applied to achieve a reliable detection and quantification - examples are known with 10 tons of salt (Knop 1878) or even with 50 tons of road salt (Batsche et al. 1970). Apart from the logistic challenge to dissolve 50 tons of salt (the injection process took $8 \mathrm{~h}$ ), also today ecotoxicological questions will arise, in particular regarding the place of injection; nevertheless, both tests have been successful with clear BTCs. Other suitable salt tracers which have been successfully applied are various chlorides $(\mathrm{NaCl}, \mathrm{KCl}, \mathrm{LiCl}$, $\mathrm{SrCl}_{2}, \mathrm{CaCl}_{2}$, etc) and bromides (KBr, $\left.\mathrm{NaBr}, \mathrm{LiBr}, \mathrm{NH}_{3} \mathrm{Br}\right)$.

\section{Deuterium $\left({ }^{2} \mathrm{H}\right)$}

In karst aquifers the stable isotope tracer deuterium has been applied rarely due to the limited availability of enriched deuterium (Benischke et al. 2003; Luhmann et al. 2012). In a multi-tracer long-distance test (over $1 \mathrm{~km}$ ) in an alpine karst area in Austria, the four tracers uranine $(18.1 \mathrm{~g})$, sulphorhodamine G (15.3 g), deuterium (7,619 g) and sodium bromide $(3,842 \mathrm{~g})$ could be compared directly for their transport properties and relative conservative behaviour under predominant conduit flow conditions (Leis and Benischke 2004). Recovery rates of the fluorescent dye tracers are usually somewhat lower than for bromide and deuterium. Conduits partly filled with sediments can retain dye tracers more than the others. This is also an example to illustrate the question as to what is a conservative tracer and which tracer can be used as a reference tracer for comparison (Fig. 2; Table S2 in the ESM). In this case bromide can be chosen as a reliable reference tracer.

\section{Toxicity of tracers}

An important aspect is the general toxicology and ecotoxicology of inorganic salts, dye tracers and isotopes, in particular radioactive substances. Legal regulations restrict the use of chemical substances. Overview reports or detailed information on toxicological effects are given in Marking (1969), Little and Lamb (1973), Smart and Laidlaw (1977), Molinari and Rochat (1978), Lutty (1978), Benoit-Guyod et al. (1979), Smart (1984), Lichacz (1987), Field et al. (1995), Leibundgut and Hadi (1997), Brüschweiler (2007), and Gombert et al. (2010, 2017). For the commonly used inorganic salt tracers and fluorescent dyes, Behrens et al. (2001) provided an overview, although some of the toxicological information is only based on the experience of experts or literature, and less on specific new tests at the time of publication. When looking at the various toxicological data, different criteria are applied to define thresholds of toxicological risks in general. Some toxicological tests focus on the LD50 (median lethal dose) or LC50 (median lethal concentration) data, on mutagenicity, teratogenicity, genotoxicity, carcinogenicity, and ecotoxicological effects with respect to selected test species. It makes a difference to evaluate toxicity for tracer concentrations at the place of injection or at the place of sampling or field measurement. Another problem is the unexpected exceedance of a threshold concentration, which could happen during a tracer test. High concentrations that exceed the legal accepted thresholds might occur at the place of injection, but usually the time of such high concentrations is rather short at the active sinkholes or ponors, whereas at the place of measurement or sampling the concentrations are hopefully in the acceptable legal range, although exceptions (shorttime exceedance) in single cases cannot be excluded. Ecotoxicological considerations become more and more important to assure an ecologically intact biodiversity both at the place of injection and the place of measurement or sampling. Most of the toxicological information has the focus on ecotoxicity in general, but less or not at all on human health risks. A newer overview on the toxicology of fluorescent dye tracers and also on human health risks was given by Field et al. (1995) and more detailed in Field (2005), who also takes into account expected environmental concentrations (EECs) for injection sites with estimations performed with 


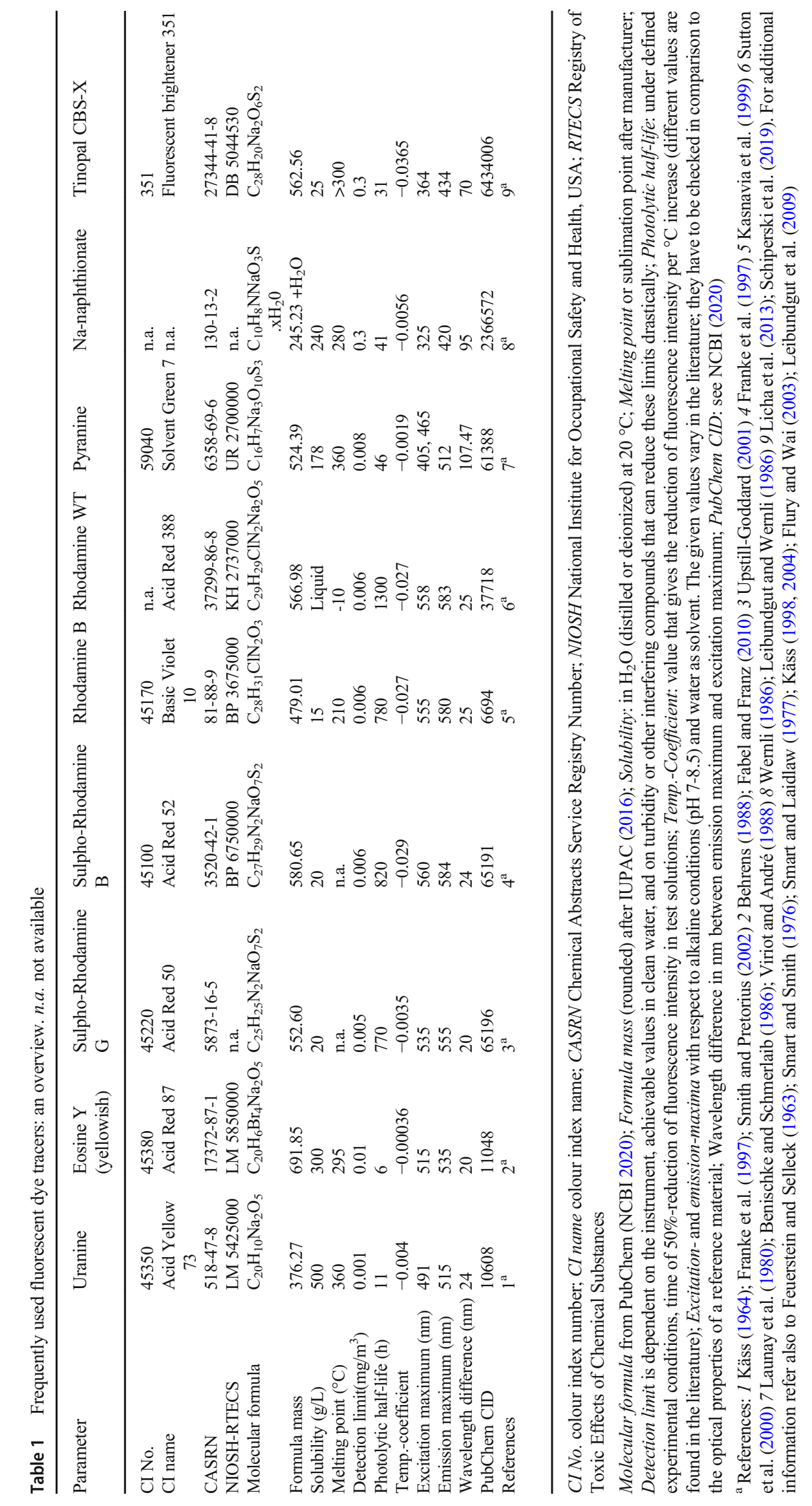


Table 2 Salt tracers: an overview

\begin{tabular}{|c|c|c|c|c|c|c|c|}
\hline Salt tracer & Formula & CASRN & Formula mass & $\begin{array}{l}\text { Solubility } \\
\left(\mathrm{g} / \mathrm{L} ; 25^{\circ} \mathrm{C}\right)\end{array}$ & $\begin{array}{l}\text { Solubility } \\
\left(\mathrm{g} / \mathrm{L} ; 10{ }^{\circ} \mathrm{C}\right)\end{array}$ & $\begin{array}{l}\text { Density } \\
\left(\mathrm{g} / \mathrm{cm}^{3} ; 20^{\circ} \mathrm{C}\right)\end{array}$ & $\begin{array}{l}\mathrm{LD} 50 \\
(\mathrm{mg} / \mathrm{kg})\end{array}$ \\
\hline Ammonium bromide & $\mathrm{NH}_{4} \mathrm{Br}$ & $12124-97-9$ & 97.94 & 780 & 672 & 2.43 & 2,714 \\
\hline Lithium bromide $^{\mathrm{a}}$ & $\mathrm{LiBr}$ & $7550-35-8$ & 86.85 & 1,804 & 1,506 & 3.46 & 1,800 \\
\hline Potassium Bromide & $\mathrm{KBr}$ & $7758-02-3$ & 119.00 & 676 & 595 & 2.74 & 3,070 \\
\hline Sodium bromide ${ }^{\mathrm{a}}$ & $\mathrm{NaBr}$ & $7647-15-6$ & 102.89 & 943 & 848 & 3.20 & 3,500 \\
\hline Lithium chloride $^{\mathrm{a}}$ & $\mathrm{LiCl}$ & $7447-41-8$ & 42.39 & 843 & 738 & 2.07 & 526 \\
\hline Sodium chloride ${ }^{\mathrm{a}}$ & $\mathrm{NaCl}$ & $7647-14-5$ & 58.44 & 359 & 357 & 2.17 & 3,000 \\
\hline Potassium chloride ${ }^{\mathrm{a}}$ & $\mathrm{KCl}$ & $7447-40-7$ & 74.55 & 354 & 309 & 1.99 & 2,600 \\
\hline Magnesium chloride & $\mathrm{MgCl}_{2}$ & $7786-30-3$ & 95.21 & 558 & 535 & 2.33 & 2,800 \\
\hline Strontium chloride & $\mathrm{SrCl}_{2}$ & $10476-85-4$ & 158.53 & 546 & 491 & 3.05 & 2,250 \\
\hline Potassium iodide & $\mathrm{KI}$ & $7681-11-0$ & 166.00 & 1,477 & 1,336 & 3.12 & 2,779 \\
\hline Sodium nitrate & $\mathrm{NaNO}_{3}$ & $7631-99-4$ & 84.99 & 909 & 798 & 2.26 & 1,267 \\
\hline Potassium nitrate & $\mathrm{KNO}_{3}$ & $7757-79-1$ & 101.10 & 382 & 214 & 2.11 & 3,750 \\
\hline Ammonium nitrate & $\mathrm{NH}_{4} \mathrm{NO}_{3}$ & $6484-52-2$ & 80.04 & 2,119 & 1,506 & 1.72 & 2,217 \\
\hline Ammonium sulfate & $\left(\mathrm{NH}_{4}\right)_{2} \mathrm{SO}_{4}$ & $7783-20-2$ & 132.14 & 761 & 727 & 1.77 & 2,840 \\
\hline
\end{tabular}

${ }^{\text {a }}$ Frequently used salt tracers

CASRN Chemical Abstracts Services Registry Number, Formula mass from IUPAC (2016), Solubility and density data from Rumble et al. (2019), LD50 (median lethal dose) for rats from material safety data (MSD) from PubChem (NCBI 2020), LD50 data do not replace a careful investigation of adverse effects on different species and ecotoxicity

the Efficient Hydrologic Tracer-Test Design (EHTD) program (Field 2003a). EECs are defined as the concentration threshold of a substance in an environmental system on the basis of usage, transport and fate of that substance. It should be kept in mind that authorities strictly ask for evidence-based toxicological information about the tracers intended to be used in a test. In case of doubt, an additional enquiry has to be done.

\section{Execution of tracer tests}

\section{Planning, type and amount of tracer}

When planning a test, it is necessary to clarify the boundary conditions, starting with the collection of basic information about hydro-meteorologic, hydrochemical, and geologic data, as well as the legal, regulatory and administrative framework
Fig. 2 Comparison of deuterium, bromide, uranine (UR) and sulpho-rhodamine G (SRG). Insitu-measurements of dye tracers with a fiberoptic fluorometer and bromide with ion-selective electrode (ISE), from water samples (lab). Bromide measured with IC, and deuterium with mass-spectrometry. Differences in concentrations between UR (in situ and lab) and SRG (in situ) originate from different instrument sensitivities, possibly also from uncertainties in calibration procedures. Tracer concentrations are normalised to the injection mass of each tracer (refer also to Table S2 in the ESM)

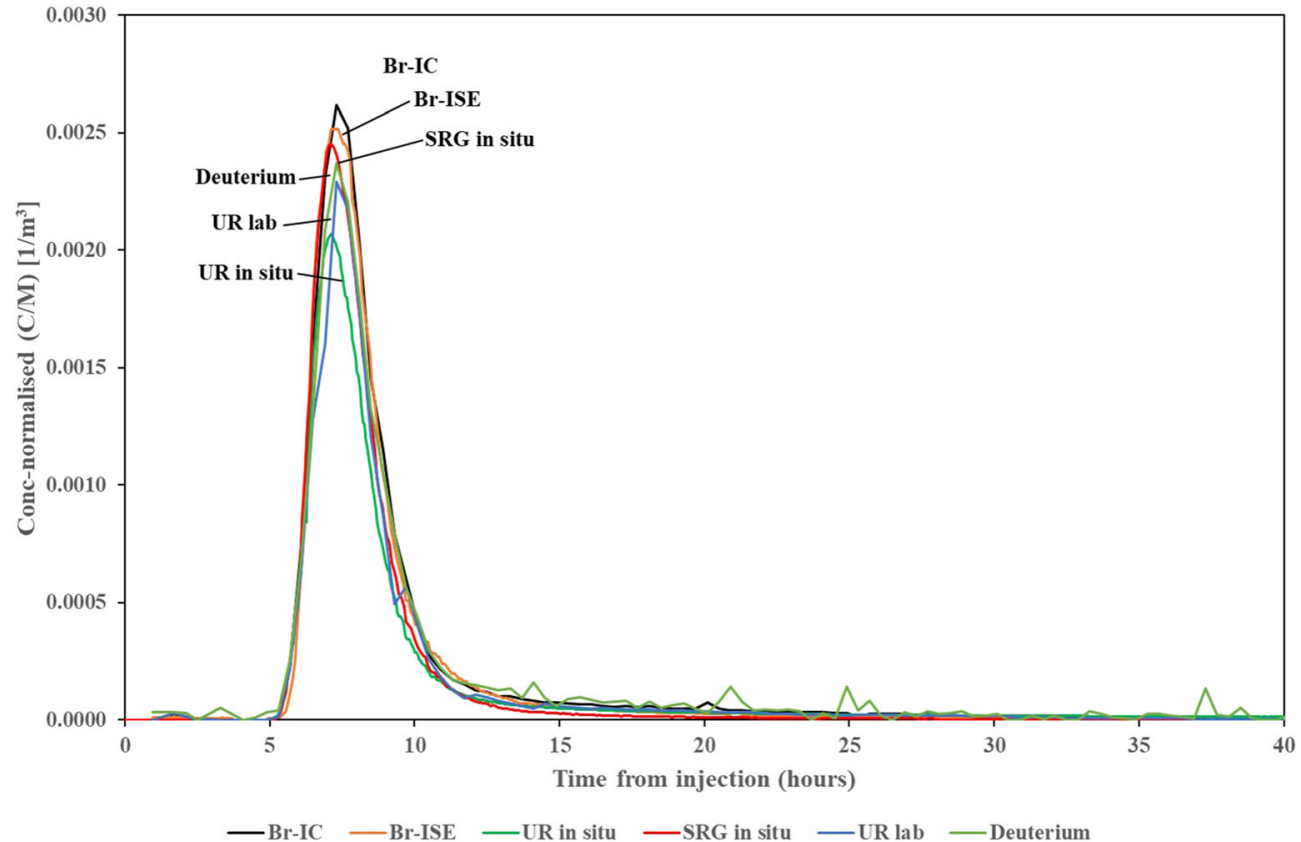


and private properties concerned. Beside the choice of an appropriate tracer also the choice of the necessary amount is a challenge, in particular for long-distance tests. The amount of tracer varies between a few grams up to more than $100 \mathrm{~kg}$, depending on the expected dilution in the aquifer and the flow distance. Up to $160 \mathrm{~kg}$ of uranine are reported from longdistance tracer tests (Maurin and Zoetl 1967; Milanovic 1976). There are many recommendations, which can be summarized in the statement: As much as necessary, as little as possible. Field (2003b) collected 33 formulas from the literature for the estimation of the necessary tracer mass. The formulas are based on a number of parameters such as average discharge, distance between injection and sampling place, expected time of the first detection and the peak of a BTC, desired peak concentration, specific coefficients for the type of tracer, and others. All formulas published have been developed by the authors from experience and no one can cover all the various actual conditions during a test. At best they provide a first estimate. Another approach is, in particular for karst terranes, to apply a simple one-dimensional (1D) advection-dispersion model (assuming mainly conduit flow), and to vary the parameters of such a model to get a plausible estimate of the suspected BTC (Schudel et al. 2002; Field 2003a; Worthington and Smart 2003).

\section{Injection of tracer}

Introducing a tracer into a system can occur as instantaneous or continuous injection. A kind of continuous injection is also irrigation or sprinkling, simulating a rainfall event. Instantaneous injection into active sinkholes (ponors) usually produces a short-term pulse, which will be idealized and simplified in modelling as a Dirac pulse. In practice there is some duration of this type of injection from a few seconds up to several hours (Batsche et al. 1970). A continuous injection with constant inflow rate will be applied rarely. An interesting long-term tracer test with three successive injections and different injection modes was described by Kogovsek and Petric (2014) in the karst around the cave Postojnska jama (Slovenia). In two of the tests the tracers were injected into an excavation pit with bare rock surface at its basis, and in one test nearby directly on the surface of topsoil only with subsequent "flushing" by rain. Samples were taken over a period of up to 11 years at drip-water places in the cave. This example shows that with artificial tracing, interesting insights into long-term infiltration and recharge processes can be achieved. Irrigation of test plots with a defined sprinkling rate in a karstic area may give interesting information about the effect of rainfall on the response of a karstic system or the infiltration process via topsoil and epikarst. In karst massifs with a thick vadose zone (sometimes several hundred meters or even more than $1 \mathrm{~km}$ ) introducing a tracer will result in some or even considerable loss of tracer due to adsorption on dry rock surfaces. This can also happen when introducing the tracer in an uncased borehole. There is practically no way to distinguish between the amount of tracer lost in such a way and the amount which is permanently adsorbed on sediments or trapped in aquifer compartments with more or less stagnant water.

Tracer tests in boreholes or wells need special equipment and detailed planning of the injection procedure. Boreholes in karstified areas would intersect open cave passages usually only randomly (Groves 2007; Palmer 2007). Considerable loss of drilling fluid is frequent in karstified rock, even if there are no surface karst phenomena or accessible caves. Detailed localisation of such zones of fluid loss and permeability tests allow one to perform the injection properly (injection in the uncased borehole, using single or double packers, labelling of the entire water column, etc.). Borehole dilution tests with tracers (single-well tests) may give some estimation of permeability in the vicinity of the bore, but can also give first hints on general flow direction when using special downhole probes (e.g GEOTECH AquaVision Colloidal Borescope, or radiometric probes with flow direction device). Well-to-well tests under natural gradient conditions may fail even if the wellmonitoring network seems to be dense enough. A better chance to be successful might be a test under forced gradient conditions. Well-to-spring tests are likely more successful if the aquifer flow-field converges to the spring, but can be unsuccessful if dilution in the aquifer is too high or flow velocities are too small. Conversely, long mean residence times inferred from isotope investigations do not allow one to conclude that a contamination risk does not exist. Tracer tests in such cases can give a positive response, as the labelled water volume represents only a short-term component of the entire runoff. An overview of the problematics of such tests is given in Smart and Worthington (2004), Ford and Williams (2007), Palmer (2007), and Milanovic (2018).

\section{Sampling of tracers}

Sampling should be based on a detailed sampling strategy after having mapped all possible resurgences. At some field sites direct manual sampling could be enough, at other sites automatic sampling will be necessary, and at special places monitoring at dense intervals is desirable. A scheme of a possible sampling program is given in Benischke et al. (2007). The actual place of sampling is also of some importance if sampling sites with water treatment facilities are included. Chlorination (Deaner 1973), ozonation and UV-irradiation or other techniques of disinfection affect considerably fluorescent dye tracers and microbial tracers. This could lead to a completely negative result; therefore, fluorometric field measurements or samples should be taken before the water enters the treatment facility. Moreover, different sampling methods are necessary for freely accessible locations at springs, 
streams, and for boreholes. Procedures of sampling, transport and storage of samples are described in the textbooks already mentioned as well as in textbooks of general hydrogeology and field methods. Special care and if necessary appropriate conservation measures have to be applied for samples of fluorescent dyes or for microbial tracers.

Special sampling can also be done with small bags of activated carbon (charcoal). Other adsorption techniques, e.g. with cotton wool, cellulose or specific resins (Close et al. 2002) may be equivalent. It is a cheap method, very easy to handle, and charcoal bags can be produced very easily (Dunn 1957; Lallemand and Paloc 1964; Bauer 1967, 1972; Perlega 1976; Bauer and Perlega 1980; Aley 2016). The experience shows that activated carbon adsorbs dye tracers, but also adsorbs any other adsorbable substance. The adsorbate is then fixed and can be analysed some time after sampling. Usually (at least valid for more or less "clean" karst waters), analysis of a dye tracer captured by charcoal will give acceptable results also decades after sampling. Charcoal bags were used in a tracer test with uranine in 1968 in the Northern Calcareous Alps (Bauer 1969). A review of the charcoal samples in 1996, after 28 years, showed acceptable results. Charcoal bags unspecifically accumulate the dye tracer during the time they are exposed to the water. The time resolution of charcoal sampling is limited to the entire duration of the exposure; therefore, the exact time at which the tracer was adsorbed is always unknown. Moreover, it has to be taken into account, that the charcoal fixes adsorbable substances according to their affinity to freely available adsorption places on the surface of the charcoal grains. This can lead also to negative results if substances of higher grain-surface affinity have taken up the entire available adsorption capacity. Smart and Simpson (2002) investigated charcoal detectors for their capability of contaminant screening with different laboratory elution methods. Charcoal cannot be used for every dye tracer (e.g. sodium naphthionate, amino $\mathrm{G}$ acid), and results from charcoal bags can also not be used for quantitative evaluations. At best, a "semi-quantitative" evaluation is possible. Usually, charcoal bags are used for sampling points of minor significance that cannot be accessed in a short time or every day. Sometimes they are used in addition to water samples to cover concentration levels which are near or below the detection limit of the dye tracer in water samples, but a tracer test with only charcoal bags cannot be recommended.

\section{Background of tracer}

Background can be defined as a measured signal overlapping the tracer signal. It originates either from the same tracer or from other substances or from both. An important part of a sampling or measurement program is to record the natural background for a tracer. A detailed knowledge of the natural variability is necessary for proper consideration of the background during breakthrough of the tracer. For salt tracers, a common water analysis will provide sufficient information. For fluorescent dye tracers fluorimetric analysis of samples or online monitoring is necessary. If charcoal sampling is in the sampling program, then also several charcoals (preferably multiple charcoals for the same period to get information about the adsorption variability of the charcoal bags) have to be exposed prior to the injection for a sufficient period of time. Usually there is no control about what will happen with the background during a breakthrough, especially at places where no upstream control is possible. Some estimations can be achieved when background observation is performed for a sufficiently long period before the tracer test and also after the end of the main measurement or sampling program. For all tracers, especially for dissolved tracers, it can happen that the background fluctuation is sometimes higher than the tracer signal at the first detection. In this case it is hard to establish a reliable background level which has to be substracted from the total tracer signal. A possible approach is a clear definition of a range of background variation taken into account for the further evaluation in particular for the calculation of recovery rates. An in-depth analysis of the problematics of background handling was provided by Smart and Karunaratne (2002), analysing a set of 168 daily water samples from an agriculturally influenced suburban catchment; they concluded that a generalisation of their findings cannot be justified. This means that background considerations have to be applied individually for each catchment and specific tracer test. Bailly-Comte et al. (2018) showed how to distinguish the tracer signal acquired by a fieldfluorometer from the natural background coming from dissolved and suspended inorganic and organic substances.

\section{Calibration and control samples}

During a tracer test, usually, sampling occurs manually or automatically via installed samplers or with field instruments. Field instruments have to be maintained regularly. Especially, online $\mathrm{pH}$ - or ion-selective electrode (ISE) measurements need repeated recalibration, but also field fluorometers have to be calibrated regularly. Calibration procedures in the field are inherently less accurate than laboratory procedures. For fluorescent dye tracers, it is known that the fluorescence intensity of some of them is considerably pH-dependent, e.g. for pyranine, uranine, and eosine $\mathrm{Y}$, and that the full development of fluorescence to a constant intensity level (and therefore to the maximum sensitivity) is usually at a $\mathrm{pH}$ above 8 or 8.5 . A field calibration can only be done at a distinctive date and time and is sensu stricto valid only for this, but can be stable over a certain time period. A possible approach is to take so-called control samples during the regular maintenance of the instrument and to measure the tracer under stable laboratory conditions. Later, the field data can be correlated with the lab samples from the same date and time, and the field data can be calculated for their "true" concentration values. 


\section{Instrumentation and analytics of tracers}

\section{General remarks}

Present-day laboratory or field instruments offer a wide range of analytical procedures with high selectivity and high sensitivity, some of them with extraordinary detection limits. Common laboratory methods for analysis of inorganic chemical compounds are ion-chromatography (IC), inductively coupled plasma optical emission spectrometry (ICP-OES), mass spectrometry (ICPMS), or other coupled analytical devices. It is also possible to work with much cheaper ISEs, but usually with a reduced sensitivity. It is also a matter of cost as to which instruments can be installed. All of them are able to measure concentrations in the ppm- to ppb-range, in some cases also in the ppt- or sub-pptrange. Several compounds can be measured at higher concentrations with conventional UV/VIS-spectrophotometers, others need spectrofluorometers. For fluorescent dye tracers, a variety of fluorometric instruments is available. An overview of laboratory fluorescence spectrometers can be found in Si et al. (2017). For fluorescent dye tracers, spectrofluorometers with versatile scanning abilities (dual or double monochromotors, synchronous-scan functions, excitation-emission-matrix (EEM) generation, spectrum evaluation capabilities, etc.) are standard. Other analytical techniques use capillary electrophoresis (CE) with laser excitation or high-performance liquid chromatography (HPLC).

Field instruments for standard chemical and physical parameters can measure on-site, or in situ with the sensor probe immersed in the water. Typical parameters for field instruments are electrical conductivity, $\mathrm{pH}$-value, dissolved oxygen, turbidity, wavelength-specific spectral absorption coefficient, and various ionic compounds.

Modern field instruments can be operated over a considerable length of time (energy supply from the public system, generators, batteries or solar panels) depending on the measurement interval and the installed storage capacity. They can be equipped with data loggers and additionally with a direct transmittance capability of data via the conventional telephone network, or via mobile telephone. Online measurements onsite (after channeling-off or pumping of water) or in situ with subsequent data transmission via satellite could be realized in several monitoring and tracer test projects (Stadler and Skritek 2001) and in karst hydrogeologic investigations with additional implementation of event-triggered sampling programs (Stadler et al. 2010).

\section{ISE techniques}

Ion-selective electrodes (ISE) have been used in karst hydrogeology since the first half of the twentieth century mainly for onsite and in situ measurements of some hydrochemical parameters. Probably, the first in situ use of ISEs in a tracer test was in
1942 in the karst area of Warstein (Westphalia, Germany), reported by Richter (1944) and Mitoff (1944). Within the activities of the Association for Tracer Hydrology (ATH), a karst spring (Source de Areuse in the Suiss Jura) was monitored for water temperature, electrical conductivity, and sodium. Sodium from the long-term measurements and on-site from a tracer test was measured with acceptable resolution and accuracy with an ISE and the measurements were recorded on a strip-chart recorder (Müller and Zötl 1980). As with all ISEs they have to be calibrated or recalibrated in rather short periods to assure acceptable accuracy. During a tracer test the ISE response on the respective ion follows the time-dependent change of concentration during breakthrough (beside cross-sensitivity to other ionic compounds and electrode drift over time). It could be observed that the relationship between the measured signal (usually in $\mathrm{mV}$ ) and the corresponding concentration shows a sometimes significant hysteresis between the rising and falling limb of the BTC. This means that the same electrode signal represents different concentration values, and therefore has to be calibrated appropriately. For more details on how to handle this ISE-hysteresis effect, see Fig. $\mathrm{S} 1$ in the ESM.

\section{Field fluorometry}

Field fluorometers are able to measure on-site or in situ. Various field fluorometers with flow-through cells (e.g. Schnegg and Doerfliger 1997; Smart et al. 1998; Schnegg 2002), or submersible fluorometric probes (e.g. TURNER Designs SCUFA III; YSI 6130 Rhodamine WT Sensor; ALBILLIA GGUN-FL24; GEOTECH AquaTroll Rhodamine WT) or with fiber-optics (LLF-M; Barczewski 1986; Benischke and Leitner 1992; Ghodrati 1999) are described.

For in-situ measurements, a flow-through cell or a fiber guide has to be immersed in the water. In both cases the fluorescent signal will be detected directly in the fluid. This is not necessarily limited to short distances. Halogen lamps, high-performance LEDs or laser diodes (Schnegg, 2008) have been used as excitation sources. Probably the first hint on the possibility to use laser technology for dye tracer analytics could be found in Käss (1964), only 4 years after the invention of the first functioning laser by Maiman in 1960.

Another approach is the LLF-M fiberoptic fluorometer (Fig. 3). Up to six modules with different filters can be mounted in one housing. Use of the lock-in technique and a shielded fiber tip largely avoids the adverse effects of ambient stray light. Fiber guides with different lengths (up to $50 \mathrm{~m}$ with acceptable attenuation of the tracer signal) can be plugged on to the instrument. A field calibration is possible and measurements are stored in the internal data logger. Measurements in turbid water showed some advantages of the geometric front design of the excitation/emission 

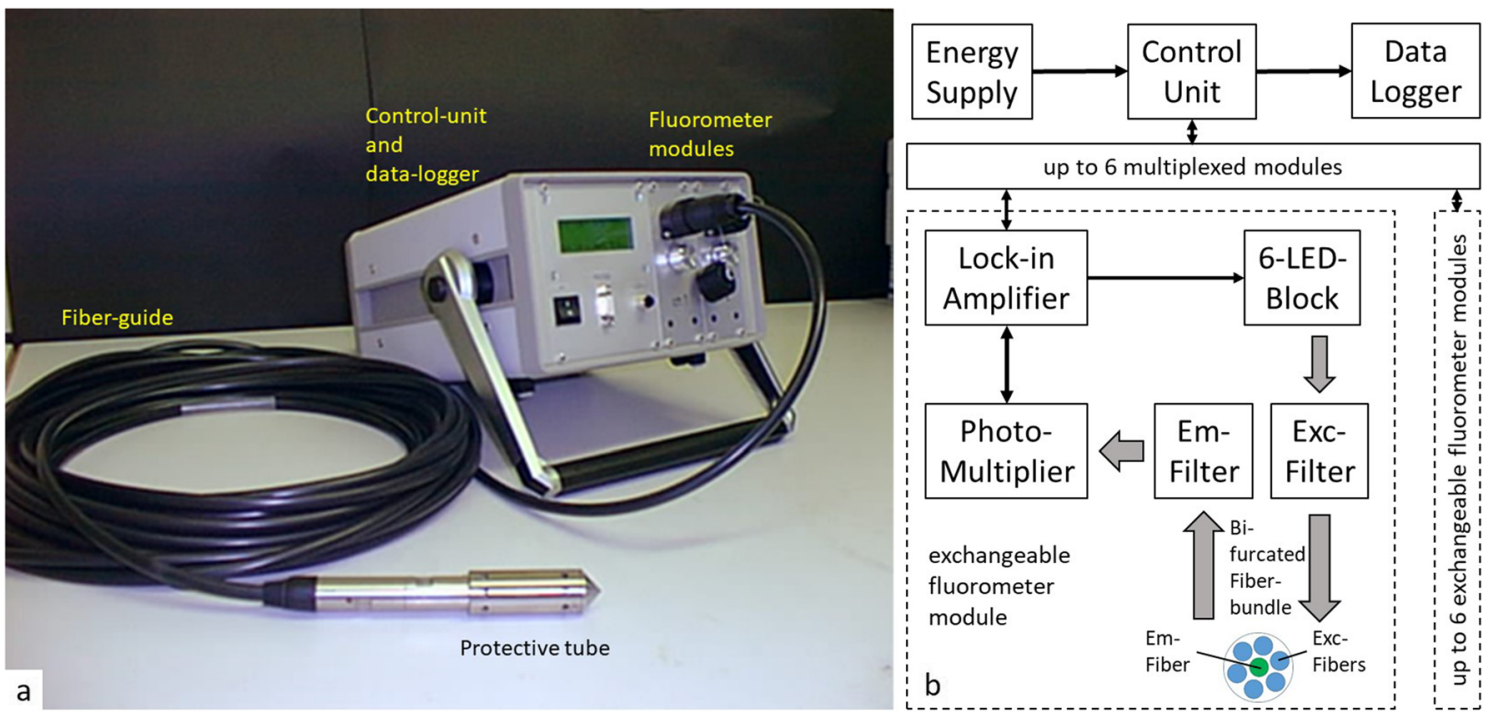

Fig. 3 LLF-M fiberoptic fluorometer with two channels and fiber-guide (Dr. Walter Gotschy: Büro f. Optik, Physik u. Tracertechnik); a total view of the instrument with fiber-guide, $\mathbf{b}$ schematic sketch of instrument details, Exc Excitation, Em Emission

path at the tip of the fiber-guide compared to a rightangle geometry (Hodel and Stoller 2000).

An experimental setup of a Nd-YAG microchip laser with fiberoptics for the in-situ detection of Rhodamine WT with a detection limit of $100 \mathrm{pg} / \mathrm{g}$ was described in detail by Moulin and Vitart (1998). In recent years a number of low-cost instruments ("pocket-fluorometer") have appeared on the market. Due to the simplification of the hardware as a compromise between performance, instrument size and costs, a reduced selectivity and sensitivity has to be accepted (e.g. Turner Designs Picofluor handheld fluorometer; Poulain et al. 2017). Recently, a low-cost instrument based on the adaption of a cell-phone using its flash-light as a light source was developed and described (Hossain et al. 2014).

\section{Synchronous scan techniques}

Fluorescence intensity measurements usually are performed as a measure of tracer concentration. Additionally, fluorescence lifetime measurements are possible (Seidlitz and Behrens 1991), which could also be helpful for the identification of fluorescent substances. The standard procedure is the synchronous scan technique with constant wavelength difference which was developed by Horst Behrens in 1969 and was at first described (in German) in an annual report (Behrens 1970) of his Institute for RadioHydrometry in Munich. A short time later, Lloyd (1971) published the same technique for applications in the identification of crude oil or in forensic sciences. Another technique involving collecting a set of emission spectra with constant step variation of the excitation wavelength produces an excitation-emissionmatrix (EEM). It is a very helpful tool to characterise waters with higher content of dissolved organic matter (DOM) or complex mixtures of organic contaminants such as PAHs (Baker and Lamont-Black 2001; Borup 2008; Bailly-Comte et al. 2018).

With the standard constant wavelength difference technique, it is possible to measure the dyes most commonly used in hydrology such as Na-naphthionate, pyranine, fluorescein sodium (uranine), eosine $\mathrm{Y}$, sulpho-rhodamine G, sulphorhodamine $\mathrm{B}$, rhodamine $\mathrm{WT}$, and rhodamine $\mathrm{B}$ with high sensitivity and selectivity, and with reduced influences from stray light. For more details on the synchronous scan technique refer to the Table $\mathrm{S} 1$ of the ESM.

\section{Chromatographic techniques}

Powerful analytical tools include the chromatographic methods (TLC, HPLC) coupled with fluorescence detectors, or laser-induced fluorescence and detection. The advantage of chromatographic methods is the clear separation of an unwanted background of substances. These methods have high selectivity and sensitivity, some of them with extraordinary detection limits in the ppt- and sub-ppt range. Thin-layer chromatography (TLC) for tracer analytics was described by Rochat et al. (1975), Bub et al. (1979), Bub and Hötzl (1980), and Ackermann and Hötzl (1984) with detection limits of $10^{-4} \mathrm{mg} / \mathrm{m}^{3}$ depending on the tracer. The TLC technique is more laborious and time-consuming than the conventional synchronous scan technique and can be an alternative, but does not play an important role in standard tracer analytics.

High performance liquid chromatography is another chromatographic method often coupled with enrichment techniques (Laane et al. 1984; Hofstraat et al. 1991; Suijlen et al. 1994; Franke et al. 1997; Ikeyaa et al. 2009). Detection limits vary between 0.3 and $1.7 \times 10^{-5} \mathrm{mg} / \mathrm{m}^{3}$ depending on the 
tracer and the used enrichment technique. These HPLC applications were developed mainly for the detection of fluorescent dyes in surface water or in sea water, but can be adapted for the analysis of karst groundwater. Automated HPLC techniques can be recommended for difficult problems of dye tracer separation from other fluorescent compounds in a mixture. There is usually no capability for EEM generation. The technology is more expensive than conventional spectrofluorometry, and needs staff experienced in chromatographic separation techniques.

\section{Capillary electrophoresis (CE) and other coupled techniques}

$\mathrm{CE}$ is capable of detecting fluorescent dye tracers at a very low level (e.g. Ferguson 1997; Ferguson et al. 1998; Brumley and Farley 2003). An application with coupling of different analytical techniques (HPTLC/AMD - high-performance thinlayer chromatography with automated multiple development and Nano-Chip-LC/QTOF-MS - nano-chip liquid chromatography coupled with quadrupole time-of-flight mass spectrometry) was developed by Weiss et al. (2008) for rhodamine dyes and their metabolites in 488 groundwater samples. Neither technique is standard in tracer laboratories yet.

\section{Evaluation and interpretation}

The success of a tracer test depends on many different factors. A test with no result, i.e. no detection of a tracer in any of the sampling stations proves usually nothing. Possible reasons should be discussed (e.g. too little tracer injected, tracer degradation, missing sampling stations, hidden flow-paths, improper analytics, etc.). Also, episodic or erratic occurrence of a tracer cannot be taken as a plausible result without further assessment; however, a test with a clear BTC can be seen as successful.

\section{Data plausibility and uncertainties}

Raw data from laboratory measurements of water samples or insitu data from field instruments have to be evaluated first for plausibility. After taking into account all influential factors, further parameters such as tracer concentration or mass flow at a distinctive moment, time of travel, transport velocities, tracer recoveries and other hydraulic parameters can be derived (Jones 1984). All measurement techniques rely on proper calibration of the used instruments, on observing $\mathrm{pH}$ and redox conditions, on temperature control during analysis (e.g. rhodamine fluorescence is strongly temperature dependent), and possible microbial decay. Each step before, during and after a test can contribute to the uncertainty of the results (uncertainty in the content of tracer in the delivered product, the injected amount, discharge rates, the calibration standards for instruments, and in concentration measurements). In hydrogeologic practice, these factors will usually not be considered in detail, but can influence the final result remarkably. A tracer test with respect to the entire uncertainty budget (with breakdown of uncertainties coming from all influential factors) has never been done, although some aspects about background and instrumental noise (Alexander 2005) have been investigated. A broader discussion about the tracer methods and their vulnerability to errors arising from different sources of uncertainties was given by Smart (2005).

\section{The breakthrough curve (BTC)}

The breakthrough curve (BTC; Fig. 4) depends on the specific transport properties of the used tracer, the hydrologic boundary conditions, and on the structure of the system under study. Even for the same karst system and under the same hydrologic conditions but under different geochemical influences, the BTC can vary considerably. BTCs can be unimodal with one peak or multimodal with two or more peaks. In comparative tracer tests with injection of several tracers at the same time, the tracer concentrations $(C)$ at a specific time $t$ should be normalised by the injected amount $M$ for each tracer (Eq. 1; Fig. 2).

$C(t)$ norm $=C(t) / M$

In the case of particle tracers, $C(t)$ is replaced by $N(t)$, the time-dependent number of particles, and $M$ is replaced by the total number $N$ of injected particles.

The evaluation of a BTC can be performed with specific modelling software such as QTRACER2 (Field 2002), CXTFIT (Toride et al. 1999), CXTFIT with EXCELextension (Tang et al. 2010), TRAC (Gutierrez et al. 2013), or with self-built spreadsheet programs. The former software TRACI (Werner 1998, 2004) developed for WINDOWS 95 can be run under newer operating systems only in an emulation mode (refer also to the ESM).

\section{Tracer recovery}

To calculate the tracer recovery, discharge information is needed. Discharge data have usually a greater uncertainty than analytical data. Sometimes discharge data are not accurate enough, especially for high discharge rates during flood conditions. In these cases, it can happen that the calculated recovery is more than $100 \%$ of the injected amount of tracer. Other influential factors are calibration uncertainties, background fluctuations, or tracer from other or earlier tests. The absolute mass of tracer recovery $\left(M_{\mathrm{R}}\right)$ is calculated by integration over time (Eq. 2):

$M_{\mathrm{R}}=\int_{t=0}^{\infty} Q(t) C(t) d t$ for variable discharge

$M_{\mathrm{R}}=Q \int_{t=0}^{\infty} C(t) d t$ for constant discharge 
Fig. 4 General scheme of a unimodal BTC after instantaneous injection with characteristic parameters. Characteristic moments are $t_{0}$ (time of injection), $t_{1}$ (time of first detection), $t_{\mathrm{p}}$ (time of concentration peak), $t_{\mathrm{cc}}$ (time of concentration centroid), $t_{\text {med }}$ (median time, time of 50\%recovery), $t_{\mathrm{e}}$ (time of end of observation period); recovery is represented as a cumulative curve (modified from Benischke et al. 2007)

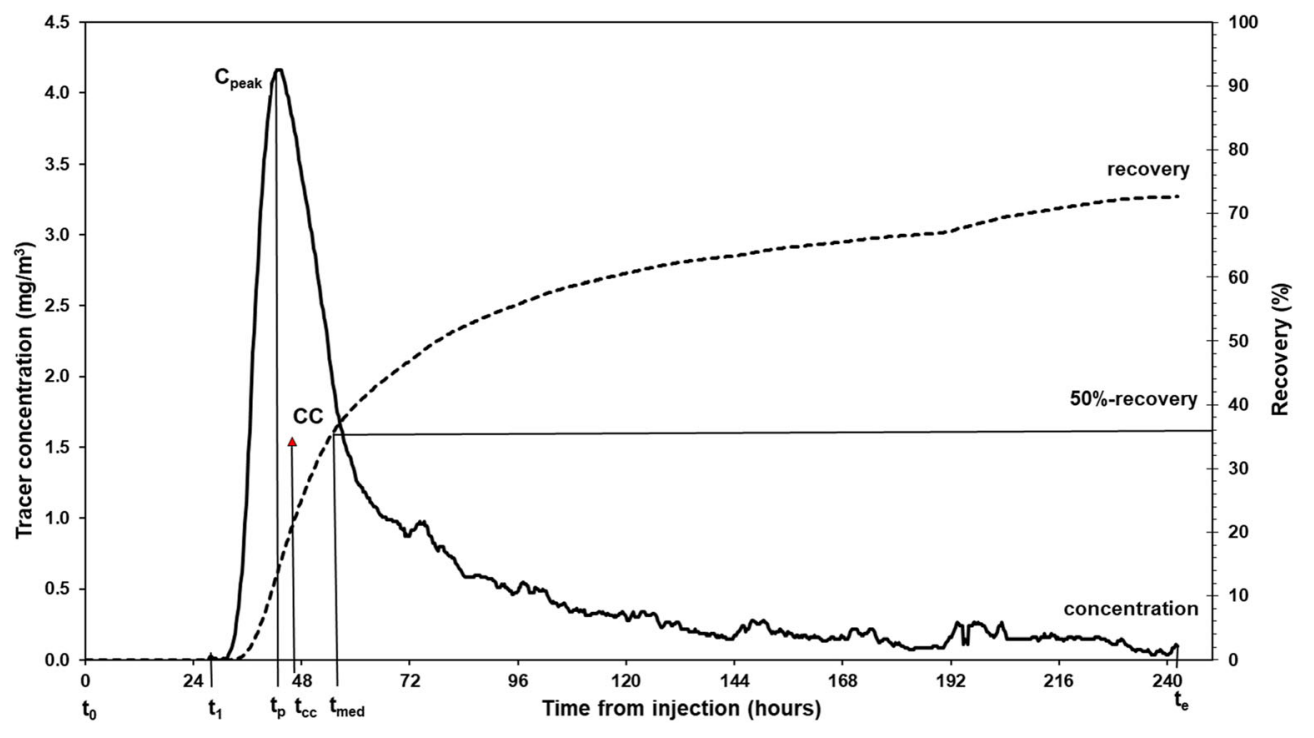

The percentage of $M_{\mathrm{R}}$ with respect to $M$ (injected mass) is the recovery rate, which is often presented as a cumulative curve together with the BTC (Fig. 4). A low recovery rate can indicate considerable loss of tracer in the system by long-term storage, adsorption, decay or degradation, or simply a too short observation time, or the existence of unobserved resurgences. For a tracer test, the total recovery is the sum of the recoveries calculated for all resurgences. In the case of an earlier termination of the observation program, an attempt can be made to extrapolate the BTC by one or a composite exponential function.

Tracers which are seen as conservative can change due to reactivity-for example, the well-known tracer uranine converts with a decreasing $\mathrm{pH}$ value from a dianion to an adsorbable cation. In a karstic environment this may be rarely the case, as the $\mathrm{pH}$ is usually above 7.5 or 8 . Above $\mathrm{pH} 8.5$, uranine forms a dianion and does not adsorb in karst conduits. Below $\mathrm{pH} 8.5$ and above $\mathrm{pH} 7.5$, a small percentage of the tracer may change to the cationic form and can be adsorbed, which results in a lower recovery.

\section{Transit times and transport velocities}

Several transit time parameters and transport velocities can be derived from a BTC. Transport velocities are based on a transport distance, which is usually defined as the linear (horizontal) distance between an input and output location, where large elevation differences can exist between them. The linear distance is therefore only a very rough estimation, because the actual flow-path is never known. To approximate the actual flow-path a tortuosity parameter can be calculated, which is based simply on a proportionality between the linear distance and the assumed actual flow-path. Assari and Mohammadi (2017) calculated tortuosity from several tracer tests applying rhodamine $\mathrm{B}$, uranine and eosine at a dam site in Iran. The values varied between 1.01 and 3.9, which depended on the scale of investigation. In many tracer tests in karst, this distance varies between $100 \mathrm{~m}$ and 5 or $10 \mathrm{~km}$, but even more than $50 \mathrm{~km}$ are known (Zötl 1974). Most important are the time of first detection, the time of peak concentration and the mean transit time. The time of first detection (in older publications "first arrival") depends largely on the definition of the background signal, the sensitivity of the analytical method, and therefore its detection limit, but also on the sampling or measurement interval. High-sensitivity measurements detect the tracer earlier than those with a lower sensitivity. Large sampling or measurement intervals may miss the correct time of "first arrival" or the time of the concentration peak. In multi-peaked BTCs, it can happen that the peaks have the same level of concentration. The time of first detection and the time of peak concentration are important in the assessment of contamination risks to water resources in general or to an existing water supply.

A first approximation of the mean transit time $\left(t_{\mathrm{C}}\right)$ can be calculated from the concentration centroid of the BTC.

$t_{c}=\frac{\int_{t=0}^{\infty} C(t) t d t}{\int_{t=0}^{\infty} C(t) d t}$

Depending on the flow conditions, a large variation of transit times occurs (from a few meters per hour or lower, up to hundreds of meters). Under flood conditions, even kilometers per hour are possible. Under extreme conditions a flood wave with pieces of fallen timber needed $30 \mathrm{~min}$ for a linear distance of $3 \mathrm{~km}$ (equivalent to $1.7 \mathrm{~m} / \mathrm{s}$ ) during an event in 1975 in Lurgrotte Cave near Graz, Austria (Benischke and Harum 1994).

\section{Modelling of tracer tests}

Karst aquifers show usually high heterogeneity and anisotropy, which considerably influence the type of BTCs (unimodal, 
multi-modal, with or without strong tailing, or irregular) of tracer tests. A BTC may reveal important information about the system under study such as geometry or structure of the karst network, travel times and velocities, and dispersion parameters. A proper evaluation can be done with mathematical modelling, which can be formulated on the basis of an adequate conceptual model. The conceptual model describes the system qualitatively and should include all factors influencing the transport of tracer through a system. From the conceptual model, a mathematical description can be set up, which consists of a set of equations that allow adequate description and prediction of the transport of water and tracer. The better the conceptual model, the more reliable the mathematical model can be, as far as the governing transport processes can be mathematically formalised. For tracer transport in karst systems, different mathematical models are available.

For a point-to-point tracer test (with instantaneous injection and a conservative tracer) mainly with tracer transport through conduits, a 1D advection-dispersion model may be adequate (Lenda and Zuber 1970; Kreft and Zuber 1978; Bear 1979), but has some constraints in proper modelling the tailing of BTCs. Maloszewski and Zuber (1985) proposed a combination of dispersion processes in conduits with diffusion processes in the rock matrix to describe the tailing effect with transport of tracer in mobile water and in quasi-stagnant or immobile water. Another approach was a superposition (Fig. 5) of flow-paths representing the final BTC (Kreft et al. 1974). An essential assumption is the complete mixing just beyond the input location and no interaction between the individual flow-paths, neglecting also diffusion processes into the rock matrix. The governing equation (Eq. 4) is then based on a 1D dispersion process with an analytical solution (Eq. 5):

$\frac{\partial C}{\partial t}=D_{\mathrm{L}} \frac{\partial^{2}}{\partial x^{2}}-v \frac{\partial C}{\partial x}$

$$
C(x, t)=\frac{M}{Q t_{0} \sqrt{4 \pi\left(\frac{D_{\mathrm{L}}}{v x}\right) /\left(\frac{t}{t_{0}}\right)^{3}}} \exp \left(-\frac{\left(1-\frac{t}{t_{0}}\right)^{2}}{4\left(\frac{D_{\mathrm{L}}}{v x}\right) \frac{t}{t_{0}}}\right)
$$

with $C$ (tracer concentration), $x$ (linear distance from injection), $t$ (time from injection), $v$ (mean transport velocity), $M$ (injected tracer mass), $Q$ (flow rate, discharge), $D_{\mathrm{L}}$ (longitudinal dispersion).

This analytical solution (originally developed for porous media) can be adapted with specific initial and boundary conditions for flow in karstic conduits, where $C(x, t)$ is the sum of $C(x, t)$-solutions for $N$ individual flow-paths.

The functioning under different hydrologic conditions could be estimated from numerous tracer tests in an alpine karst aquifer in Austria (Maloszewski et al. 1992, 1994; Werner 1998; Kübeck et al. 2012). Composite BTCs (Fig. 5) with multiple peaks or only
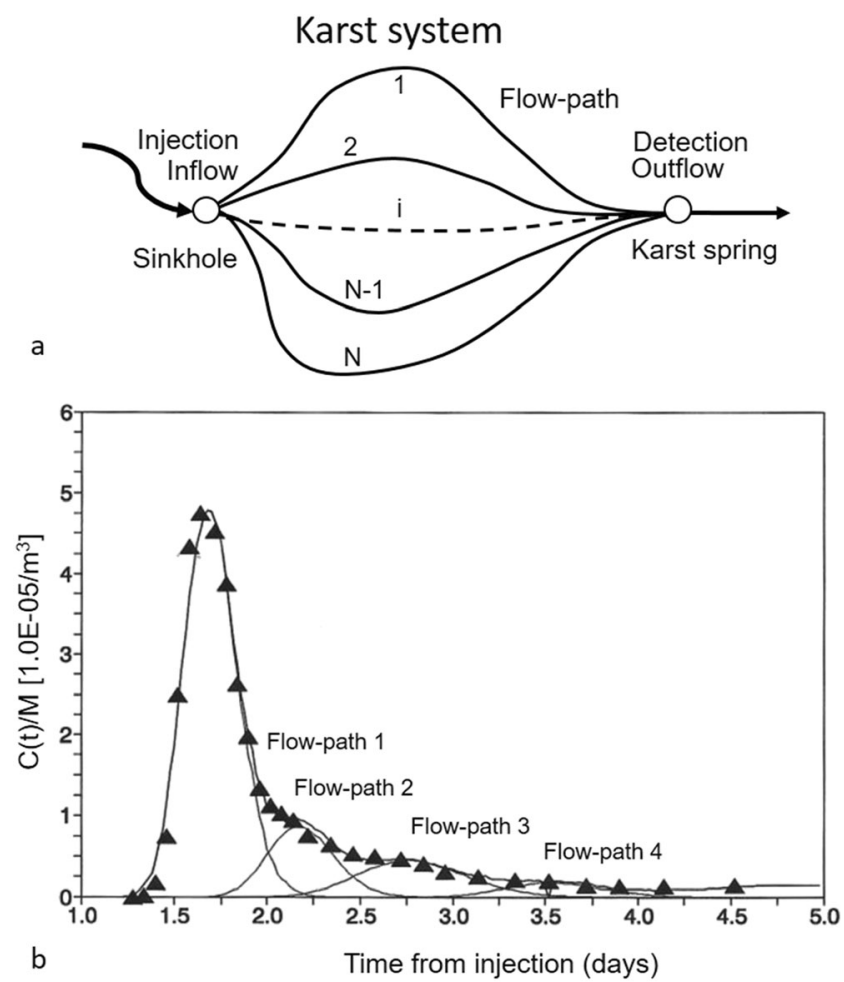

Fig. 5 a General conceptual multi-dispersion model (MDM) with transport along $N$ different flow-paths; b modelled tracer concentrations (bromide) for four flow-paths (solid lines) and measured tracer concentrations (triangles) from a test in Lurgrotte Cave in Austria (modified from Maloszewski et al. 1992)

shoulders could be resolved. Questions remained open as to whether secondary peaks in the BTC can be attributed to different real conduits or to different retardation compartments (e.g. sediment fillings, pools, etc.) in the same conduit, or to artefacts.

Another approach is the two-region nonequilibrium model which has the same target to explain the tailing of a BTC. The model assumes regions of the karst aquifer with mobile and immobile water (Fig. 6). These regions can be in a main conduit with adjacent pools with quasi-stagnant or immobile water. An exchange rate of tracer is based on a proportional concentration difference between the two regions. Diffusion processes usually are considered as negligible in conduits with fast turbulent flow (Field and Pinsky 2000; Birk et al. 2005; Geyer et al. 2007).

A recent approach (Goeppert et al. 2020) to describe the long tailing of a BTC from tests with uranine and eosine (seen as conservative tracers) in a karst system at kilometer-scale uses a continuous time random walk model (CTRW). Whereas a simple advection-dispersion model cannot describe adequately a tailing effect of a BTC, a two-region nonequilibrium model is limited in quantification of long tails. The theory behind CTRW-models was comprehensively described by Berkowitz et al. (2006). Literature on mathematical modeling of karst aquifers and tracer tests is widespread, and the reader may refer to detailed overviews (Kovács and Sauter 2007; Leibundgut et al. 2009; Hartmann et al. 2014; Turnadge and Smerdon 2014). 


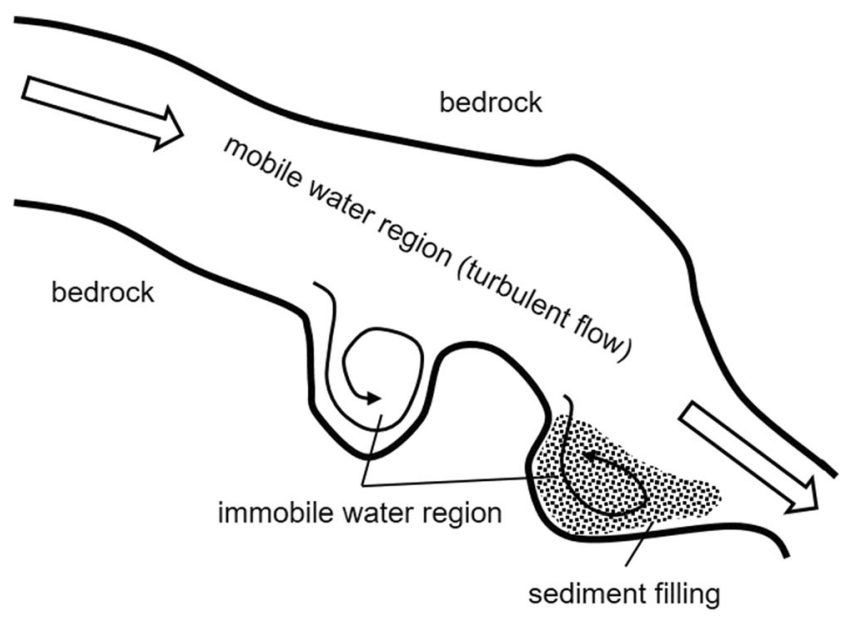

Fig. 6 Schematic plan view of a karst conduit with mobile and immobile water regions

\section{Concluding remarks}

Tracer methods are standard hydrogeologic methods and have been used for many decades to investigate karst aquifers. Their importance can be seen on the increasing number of papers published in the various scientific journals (Divine and McDonnell 2005). In general, the application of tracers has two targets: (1) to gain detailed knowledge of transport properties of substances occurring in the water cycle, because for all types of aquifers, especially karst aquifers, this knowledge is essential for proper assessment of the transport and fate of contaminants; (2) to gain more insight into the structure and the hydrological or hydrogeochemical dynamics of a karst aquifer. Tracer tests can contribute considerably to this knowledge.

Naturally occurring inorganic or organic chemical compounds, including stable and radioactive isotopes, physicochemical properties (such as temperature, electrical conductivity, $\mathrm{pH}$ value), and transport of particulate matter, can be monitored today with high temporal resolution using adequate sampling techniques and the respective sensors and data loggers. These natural tracers can reveal much of the natural dynamics in karst systems.

Artificial tracers are applied mainly in short-term investigations, from several hours up to a few years, and may not be adequate for studying long-term transport processes in deep karstic aquifers or in karst systems with thick vadose zones or aquifers that lack large conduits, where transport processes may be active for decades and more.

The charcoal sampling method is cheap and easy to handle, but the results are only qualitative. On the other hand, it is a kind of tracer enrichment technique, which can complement the results of direct water samples. A more detailed understanding of the dye adsorption processes seems to be necessary; moreover, research on more specific resins for adsorption of dyes would also be of interest.
The instruments and analytical methods used today for natural or artificial tracers provide high selectivity and extremely high sensitivity. Fluorescent dyes are, in most cases, still the most used artificial tracers, although research is needed to extend the number of suitable dyes, and to further characterise in detail their transport properties in different geochemical environments. Sophisticated laboratory and robust field techniques do not compete with each other but complement one another, although the selectivity and sensitivity, accuracy and reproducibility of laboratory techniques is still one or some orders of magnitude better than for field techniques. The choice of a specific instrument or a specific analytical technique depends on many factors, not least on the intended purpose and the costs. It is not possible to give a general recommendation for a specific instrument or analytical technique as this depends on the targets of an investigation and, as mentioned, the available financial resources.

Quantitative evaluation and interpretation of tracer test results is supported with mathematical modelling, as far as an adequate conceptual model is available and the governing transport processes can be formulated in mathematical form. Many models assume that tracers are conservative, which is in the strict sense always a simplification, as none of the tracers is ideal. For future research, an interesting question would be how and to what extent the type of tracer influences the results achieved in model calculations, i.e. are these calculations tracer dependent. This might be clarified when performing comparative tracer tests with different tracers injected at the same place, at the same time and under identical hydrologic conditions.

Deriving hydraulic properties, travel times and transport velocities, dispersion parameters, and conduit volume estimations from tracer tests is only one, and of course, an important part of the interpretation. Another part is to derive a realistic network configuration and structure for a given karst system (Smart 1988). This would be of great interest for geologists as practitioners, and in their work as consultants or authorised experts.

Supplementary Information The online version contains supplementary material available at https://doi.org/10.1007/s10040-020-02278-9.

Acknowledgements The author would like to thank the editor and two anonymous reviewers for their valuable comments, as well as Sue Duncan for polishing the English.

Funding Open access funding provided by Graz University of Technology.

Open Access This article is licensed under a Creative Commons Attribution 4.0 International License, which permits use, sharing, adaptation, distribution and reproduction in any medium or format, as long as you give appropriate credit to the original author(s) and the source, provide a link to the Creative Commons licence, and indicate if changes were made. The images or other third party material in this article are included in the article's Creative Commons licence, unless indicated otherwise in a credit line to the material. If material is not included in the 
article's Creative Commons licence and your intended use is not permitted by statutory regulation or exceeds the permitted use, you will need to obtain permission directly from the copyright holder. To view a copy of this licence, visit http://creativecommons.org/licenses/by/4.0/.

\section{References}

Abbott BW, Baranov V, Mendoza-Lera C, Nikolakopoulou M, Harjung A, Kolbe T, Balasubramanian MN, Vaessen TN, Ciocca F, Campeau A, Wallin MB, Romeijn P, Antonelli M, Gonçalves J, Datry T, Laverman AM, De Dreuzy J-R, Hannah DM, Krause S, Oldham C, Pinay G (2016) Using multi-tracer inference to move beyond single-catchment ecohydrology. Earth Sci Rev 160:19-42

Ackermann G, Hötzl H (1984) Weiterentwicklung der DünnschichtChromatographie für die Auswertung von Aktivkohle-Eluaten in der Tracertechnik [Advancement in thin-layer chromatography for the evaluation of eluates of activated carbon in tracer technology]. Steir Beitr z Hydrogeol 36:103-114

Alexander SC (2005) Spectral deconvolution and quantification of natural organic material and fluorescent tracer dyes. In: Sinkholes and the Engineering and Environmental Impacts of Karst. Proc. 10th Multidisciplinary Conf, Sept 24-28, 2005. San Antonio, Texas. ASCE Geotechnical Special Publication No 144, p 441-448

Aley TJ (2016) Using activated carbon samplers to improve detection of fluorescent tracer dyes in groundwater remediation studies. In: Rectanus HV, Rodgers P (eds) Remediation of chlorinated and recalcitrant compounds: Tenth Int. Conf. on Remediation of Chlorinated and Recalcitrant Compounds, Palm Springs, CA, May 2016, Paper A-056

Aley TJ, Fletcher MW (1976) The water tracer's cookbook. Missouri Speleol 16(3):1-32

Aley T, Beeman SL (2015) Procedures and criteria - analysis of fluorescent dyes in water and charcoal samplers: fluorescein, eosine, rhodamine WT, and sulforhodamine B dyes. Ozark Underground Laboratory. Protem, MO, https://www.ozarkundergroundlab.com/ assets/procedures-and-criteria-standard-dyes.pdf. Accessed 01/12/ 2020

Assari A, Mohammadi Z (2017) Assessing flow paths in a karst aquifer based on multiple dye tracing tests using stochastic simulation and the MODFLOW-CFP code. Hydrogeol J 25:1679-1702

Bailly-Comte V, Durepaire X, Batiot-Guilhe C, Schnegg P-A (2018) In situ monitoring of tracer tests: how to distinguish tracer recovery from natural background. Hydrogeol J 26:2057-2069

Baker A, Lamont-Black J (2001) Fluorescence of dissolved organic matter as a natural tracer of groundwater. Ground Water 39(5):745-750

Barczewski B (1986) Tracer measurements in flows. In: Wessels ACE (ed) Proc. Int. Symp. Measuring Techn. in Hydraulic Research (IAHR Section on Hydraulics Instrumentation), Delft, The Netherlands, 22-24 April 1985, Balkema, p 77-94

Batiot C, Linan C, Andreo B, Emblanch C, Carrasco F, Blavoux B (2003) Use of Total organic carbon (TOC) as tracer of diffuse infiltration in a dolomitic karstic system: the Nerja Cave (Andalusia, southern Spain). Geophys Res Lett 30(22):2179. https://doi.org/10.1029/ 2003GL018546

Batsche H, Bauer F, Behrens H, Buchtela K, Dombrowski HJ, Geisler R, Geyh MA, Hötzl H, Hribar F, Käss W, Mairhofer J, Maurin V, Moser H, Neumaier F, Schmitz J, Schnitzer WA, Schreiner A, Vogg H, Zötl J (1970) Kombinierte Karstwasseruntersuchungen im Gebiet der Donauversickerung (Baden-Württemberg) in den Jahren 1967-1969 [Combined karst water investigations in the infiltration area of the Danube (Baden-Württemberg) in the years 1967-1969]. Steir Beitr z Hydrogeol 22:5-165
Bauer F (1967) Erfahrungen beim Uraninnachweis mit Aktivkohle [Experiences with the detection of uranine in activated carbon]. In: Maurin V, Zötl J (eds), Specialists Conf. on the Tracing of Subterranean Waters in Graz, March 28-April 1, 1966. Steir Beitr z Hydrogeol 18/19:169-178

Bauer F (1969) Karsthydrologische Untersuchungen im Schneealpenstollen in den steirisch-niederösterreichischen Kalkalpen [Karst hydrogeologic investigations in the Schneealpe tunnel in the calcareous Alps of Styria and Lower Austria]. Steir Beitr z Hydrogeol 21:193-214

Bauer F (1972) Weitere Erfahrungen beim Uraninnachweis mit Aktivkohle [More experiences with the detection of uranine in activated carbon]. Geol Jb C2:19-27

Bauer F (1989) Die unterirdischen Abflussverhältnisse im Dachsteingebiet und ihre Bedeutung für den Karstwasserschutz [The subterranean discharge conditions in the Dachstein area and their consequences for the karst water preservation). Umweltbundesamt-report UBA-89-28, Ministry of the Environment, Vienna

Bauer F, Perlega W (1980) Ergebnisse des Fluoreszenztracernachweises mittels Aktivkohle [Results of the detection of fluorescent tracers with activated carbon]. Steir Beitr z Hydrogeol 32:70-74

Bauer F, Zötl J, Mayr A (1959) Neue karsthydrographische Forschungen und ihre Bedeutung für Wasserwirtschaft und Quellschutz: Ergebnisse des im Jahre 1958 vom Speläologischen Institut (Wien) im Dachsteingebiet durchgeführten Sporentriftversuches [New karst-hydrographic research and its significance for water management and spring protection: results of the spore drifting test in 1958 in the Dachstein massif carried out by the Speleological Institute, Vienna]. Wasser Abwasser 3:280-297

Bear J (1979) Hydraulics of groundwater. McGraw-Hill

Behrens H (1970) Zur Messung von Fluoreszenzfarbstoffen [For the measurement of fluorescent dyes]. Jahresbericht 1969 GSF-Bericht R 25:92-96, Inst. f. Radiohydrometrie, Munich, Germany

Behrens H (1986) Water tracer chemistry: a factor determining performance and analytics of tracers. In: Morfis A, Papadimitropoulos P (eds) Proc. 5th Int. Symp. on Underground Water Tracing (SUWT), Athens, Greece, p 121-133

Behrens H (1988) Quantitative Bestimmung von Uranin, eosin und Pyranin in Gemischen mittels Fluoreszenzmessung bei definierten $\mathrm{pH}-$ Werten [Quantitative determination of uranine, eosine and pyranine in mixtures by fluorescence measurement at defined $\mathrm{pH}-$ values]. Steir Beitr z Hydrogeol 39:117-129

Behrens H, Beims U, Dieter H, Dietze G, Eikmann T, Grummt T, Hanisch H, Henseling H, Käss W, Kerndorff H, Leibundgut C, Müller-Wegener U, Rönnefahrt I, Scharenberg B, Schleyer R, Schloz W, Tilkes F (2001) Toxicological and ecotoxicological assessment of water tracers. Hydrogeol J 9(3):321-325

Benischke R, Harum T (1994) Zur Hydrologie und Hydrogeologie des Gebietes Peggau-Tanneben-Semriach [Hydrology and hydrogeology of the region of Peggau-Tanneben-Semriach]. In: Benischke R, Schaffler H, Weissensteiner V (eds) Festschrift Lurgrotte 18941994, Landesverein für Höhlenkunde in der Steiermark, Graz, p 143-181

Benischke R, Leitner A (1992) Fiberoptic fluorescent sensors: an advanced concept for tracer hydrology. In: Hötzl H, Werner A (eds) Tracer hydrology. Proc. of 6th Int. Symp. on Water Tracing, Balkema, p 33-39

Benischke R, Schmerlaib H (1986) Pyranin: a fluorescent dye for tracer hydrology - review of physico-chemical properties, the toxicity and applicability. In: Morfis A, Papadimitropoulos P (eds) Proc. 5th Int. Symp. Underground Water Tracing (SUWT), Athens, Greece, 1986, p 135-145

Benischke R, Leis A, Stadler H (2003) Deuterium as reference in a multitracing experiment in a karst system: a comparative study. Int. Symp. on Isotope Hydrology and Integrated Water Resources Management, Vienna, May 2003, Poster IAEA-CN-104/P-67 
Benischke R, Goldscheider N, Smart CC (2007) Tracer techniques. In: Goldscheider N, Drew D (eds) Methods in karst hydrogeology. Int Contrib Hydrogeol 26:147-170

Benoit-Guyod JL, Rochat J, Alary J, André C, Taillandier G (1979) Correlations between physicochemical properties and ecotoxicity of fluorescent xanthene water tracers. Toxicol Eur Res 2(5):241-246

Berkowitz B, Cortis A, Dentz M, Scher H (2006) Modeling non-Fickian transport in geological formations as a continuous time random walk. Rev Geophys 44(2):2005RG000178

Birk S, Geyer T, Liedl R, Sauter M (2005) Process-based interpretation of tracer tests in carbonate aquifers. Ground Water 43(3):381-388

Blondel T, Emblanch C, Batiot-Guilhe C, Dudal Y, Boyer D (2012) Punctual and continuous estimation of transit time from dissolved organic matter fluorescence properties in karst aquifers, application to groundwaters of 'Fontaine de Vaucluse' experimental basin (SE France). Environ Earth Sci 65:2299-2309

Borup MB (2008) Detecting and identifying water pollution sources using fluorescence spectrophotometry. World Env. and Water Res. Congress 2008, ASCE, Reston, VA

Brumley WC, Farley JW (2003) Determining eosine as a groundwater migration tracer by capillary electrophoresis/laser-induced fluorescence using a multiwavelength laser. Electrophoresis 4:2335-2339

Brüschweiler B (2007) Markierstoffe im Bereich von Trinkwasserfassungen: Abklärung zur Humantoxizität der Fluoreszenztracer [Tracers in drinking water supplies: clarification of the human toxicity of fluorescent tracers]. GWA 2005(5):355-359

Bub FP, Hötzl H (1980) Ergebnisse der dünnschicht-chromatographischen Auswertung von Direktproben [Results of thin-layer chromatographic evaluation of water samples]. In: Müller I, Zötl JG (eds) Karsthydrologische Untersuchungen mit natürlichen und künstlichen Tracern im Neuenburger Jura (Schweiz) [Karst hydrologic investigations with natural and artificial tracers in the Neuenburg Jura, Switzerland]. Steir Beitr z Hydrogeol 32:65-70

Bub FP, Hötzl H, Wisser K (1979) Dünnschicht-chromatographischer Nachweis von Fluoreszenztracern bei hydrogeologischen Markierungsversuchen [Thin-layer chromatographic detection of fluorescent tracers at hydrogeologic tracer tests]. Steir Beitr z Hydrogeol 31:129-141

Clark I, Fritz P (1997) Environmental isotopes in hydrogeology, Lewis Publishers

Close ME, Stanton GJ, Pang L (2002) Use of rhodamine WT with XAD7 resin for determining groundwater flow paths. Hydrogeol J 10(3): 368-376

Cronin AA, Pedley S (2002) Microorganisms in groundwater: tracers and troublemakers. R6D Techn. Report P2-290/TR, Environment Agency, London, $49 \mathrm{pp}$

Dahlke HE, Williamson AG, Georgakakos C, Leung S, Sharma AN, Lyon SW, Walter MT (2015) Using concurrent DNA tracer injections to infer glacial flow pathways. Hydrol Process 29(25). https:// doi.org/10.1002/hyp.10679

Davis SN (1980) Reply to preceding discussion by Gordon V. Evans of "Ground-water tracers: a short review". Ground Water 16(6):632633

Davis SN (1986) Reply to the discussion by James F. Quinlan of "Ground-water tracers: a short review", March-April 1986 issue, v. 24, no. 2, p. 253-259. Ground Water 24(3):398-399

Davis SN, Thompson GM, Bentley HW, Stiles G (1980) Ground-water tracers: a short review. Ground Water 18:14-23

Davis SN, Campbell DJ, Bentley HW, Flynn TJ (1985) An introduction to ground-water tracers. EPA/600/2-85/022, US EPA, Washington, $\mathrm{DC}$

Deaner DG (1973) Effect of chlorine on fluorescent dyes. J Water Pollut Control Federation 45(3):507-514

Dechant M (1996) Entwicklungen zu einer verbesserten Anwendung der Sporentriftmethode [Developments for an improved application of the spore drifting method]. Steir Beitr z Hydrogeol 47:159-174
Dechant M, Maurin V, Zötl J (1958) Die Triftung gefärbter Sporen. Eine neue Methode zur Untersuchung unterirdischer Karstgerinne [Drifting of coloured spores: a new method for the investigation of subterranean karst streams]. Steir Beitr z Hydrogeol 1958:44-51

Divine CE, McDonnell JJ (2005) The future of applied tracers in hydrogeology. Hydrogeol J 13:255-258

Dunn JR (1957) Stream tracing. Bull Mid-Appalachian Region 2:7

DVGW (2005) Technische Regel, Arbeitsblatt W 109, Planung, Durchführung und Auswertung von Markierungsversuchen bei der Wassergewinnung [Technical guideline, working sheet W 109, planning, procedure and evaluation of tracer tests for water abstraction]. DVGW, Bonn, Germany

Einsiedl F (2000) Entwicklung und Anwendung neuer Fluoreszenzfarbstoffe und Partikeltracer [Development and application of new fluorescent dyes and particle tracers]. Münchner Geol Hefte B11:107

Einsiedl F, Maloszewski P (2005) Tracer tests in fractured rocks with a new fluorescent dye: pyrene-1,3,6,8-tetra sulphonic acid (PTS). Hydrol Sci J 50(3):543-554. https://doi.org/10.1623/hysj.50.3.543. 65026

Einsiedl F, Wohnlich S, Langhals H, Klotz D (1998) The Use of N,N'bis(phenyl-3,5-disulphonic-acid)-perylene-3,4:9,10-bis(dicarboximide) as a hydrogeological tracer. In: Van Brahana J, Eckstein Y, Ongley LK, Schneider R, Moore JE (eds) Gambling with groundwater: physical, chemical, and biological aspects of aquifer-stream relations. Proc. vol. of the joint conference of the Int. Assoc. of Hydrogeologists and the American Inst. of Hydrogeology, Las Vegas, Nevada USA, 28 Sept-2 Oct 1998, LCCC 98-073291, p 555-560

Einsiedl F, Langhals H, Maloszewski P, Witthüser K, Wohnlich S (2000) Application of two new fluorescent dyes and fluorescent particles in a horizontal and vertical fracture. IAHS-Publ Tracers Model Hydrogeol 262:175-179

Emblanch C, Blavoux B, Puig J-M, Mudry J (1998) Dissolved organic carbon of infiltration within the autogenic karst hydrosystem. Geophys Res Lett 25(9):1459-1462

Evans G (1980) Discussion of "Ground-Water Tracers-A Short Review" by Stanley N. Davis, Glenn M. Thompson, Harold W. Bentley and Gary Stiles, Jan.-Feb. 1980 issue, v. 18(1):14-23. Ground Water 16(6):632

Fabel S, Franz H (2010) HPLC-fluorescence detection of Eosin Y in groundwater studies. LC-GC Europe, Chester, UK

Farnleitner AH, Wilhartitz I, Kirschner AKT, Stadler H, Burtscher M, Hornek R, Szewzyk U, Herndl G, Mach RL (2005) Bacterial dynamics in spring water of two contrasting alpine karst aquifers indicate autochthonous microbial endokarst communities. Environ Microbiol 7:1248-1259

Farnleitner AH, Ryzinska-Paier G, Reischer GH, Burtscher MM, Knetsch S, Rudnicki S, Dirnböck T, Kuschnig G, Mach RL, Sommer R (2010) Escherichia coli and enterococci are sensitive and reliable indicators for human, livestock, and wild life faecal pollution in alpine mountainous water resources. J Appl Microbiol 109:1599_ 1608

Ferguson P (1997) The use of spectrofluorimetry and capillary electrophoresis/laser-induced fluorescence for the detection of fluorescent dyes in groundwater migration studies. BA Thesis, University of Nevada, Las Vegas, NV

Ferguson P, Grange AH, Brumley WC, Donelli JR, Farley JW (1998) Capillary electrophoresis/laser-induced fluorescence detection of fluorescein as a groundwater migration tracer. Electrophoresis 19(12):2252-2256

Ferronsky VI, Polyakov VA (2012) Isotopes in the Earth's hydrosphere. Springer

Feuerstein DL, Selleck RE (1963) Tracers for dispersion measurements in surface waters. Report 63-1, Calif. Univ. Sanitary Eng. Research Lab., Berkeley, CA 
Field MS (2002) The QTRACER2 program for tracer-breakthrough curve analysis for tracer tests in karstic aquifers and other hydrologic systems. EPA/600/R-02/001, US EPA, Washington, DC

Field MS (2003a) Tracer-test planning using the efficient hydrologic tracer-test design (EHTD) program. EPA/600/R-03/034 US EPA, Washington, DC

Field MS (2003b) A review of some tracer-test design equations for tracer-mass estimation and sample-collection frequency. Environ Geol 43:867-881

Field MS (2005) Assessing aquatic ecotoxicological risks associated with fluorescent dyes used for water-tracing studies. Environ Eng Geosci 11(4):295-308

Field MS, Pinsky PF (2000) A two-region nonequilibrium model for solute transport in solution conduits in karstic aquifers. J Contam Hydrol 44:329-351

Field MS, Wilhelm RG, Quinlan JF, Aley TJ (1995) An assessment of the potential adverse properties of fluorescent tracer dyes used for groundwater tracing. Environ Monit Assess 38:75-96

Flury M, Wai NN (2003) Dyes as tracers for vadose zone hydrology. Rev Geophys 41(1):37

Ford D, Williams P (2007) Karst hydrogeology and geomorphology. Wiley

Frank S, Goeppert N, Goldscheider N (2018) Fluorescence-based multiparameter approach to characterise dynamics of organic carbon, faecal bacteria and particles at alpine karst springs. Sci Total Environ 615:1446-1459

Franke C, Weserholm H, Niessner R (1997) Solid-phase extraction (SPE) of the fluorescence tracers uranine and sulphorhodamine B. Water Res 31:2633-2637

Gaspar E (1987) Modern trends in hydrology, vol 1 and 2. CRC Press

Geyer T, Birk S, Licha T, Liedl R, Sauter M (2007) Multitracer test approach to characterize reactive transport in karst aquifers. Ground Water 45(1):36-45

Ghodrati M (1999) Point measurement of solute transport processes in soil using fiber optic sensors. Soil Sci Soc Am J 63:471-479

Goeppert N, Goldscheider N (2008) Solute and colloid transport in karst conduits under low- and high-flow conditions. Ground Water 46(1): $61-68$

Goeppert N, Goldscheider N (2019) Improved understanding of particle transport in karst groundwater using natural sediments as tracers. Water Res 166. https://doi.org/10.1016/j.watres.2019.115045

Goeppert N, Hötzl H (2010) Precise method for continuous measurement of fluorescent microspheres during flow. Hydrogeol J 18:317-324

Goeppert N, Goldscheider N, Berkowitz B (2020) Experimental and modeling evidence of kilometer-scale anomalous tracer transport in an alpine karst aquifer. Water Res 178. https://doi.org/10.1016/j. watres.2020.115755

Goldscheider N, Drew D (eds) (2007) Methods in karst hydrogeology. Int. Contr. to Hydrogeology, 26, Taylor and Francis

Goldscheider N, Hötzl H, Käss W, Ufrecht W (2003) Combined tracer tests in the karst aquifer of the artesian mineral springs of Stuttgart, Germany. Environ Geol 43(8):922-929

Goldscheider N, Meiman J, Pronk M, Smart CC (2008) Tracer tests in karst hydrogeology and speleology. Int J Speleol 37(1):27-40

Gombert P, Granier D, De Seze R, Pandard P, Gondelle F, El Koulaly F, Benkada FZ, Toussaint R (2010) Toxicity and ecotoxicity of byproducts resulting from degradation of fluorescent tracers used in the karstic chalk of Normandy (France). In: Andreo B, Carrasco F, Durán JJ, LaMoreaux JW (eds.) Advances in Research in Karst Media, Springer, pp. 271-280, https://doi.org/10.1007/978-3-64212486-0 42

Gombert P, Biaudet H, De Seze R, Pandard P, Carré J (2017) Toxicity of fluorescent tracers and their degradation byproducts. Int J Speleol 46(1):23-31

Groves C (2007) Hydrological methods. In: Goldscheider and Drew (eds) Methods in karst hydrogeology, Int Contrib Hydrogeol 26:45-64
Gutierrez A, Klinka T, Thiéry D, Buscarlet E, Binet S, Jozja N, Défarge C, Leclerc B, Fécamp C, Ahumada Y, Elsass J (2013) TRAC, a collaborative computer tool for tracer-test interpretation. EPJ Web Conf 50:03002. https://doi.org/10.1051/epjconf/20135003002

Hadi S, Leibundgut C, Friedrich K, Maloszewski P (1997) New fluorescent tracers. In: Kranjc A (ed) Tracer Hydrology 97, Proc. 7th Int. Symp. on Water Tracing, Portoroz, Slovenia, May 1997, Balkema, p $55-62$

Hartland A, Fairchild IJ, Lead JR, Borsato A, Baker A, Frisia S, Baalousha M (2012) From soil to cave: transport of trace metals by natural organic matter in karst dripwaters. Chem Geol 304 305:68-82

Hartmann A, Goldscheider N, Wagener T, Lange J, Weiler M (2014) Karst water resources in a changing world: review of hydrological modeling approaches. Rev Geophys. https://doi.org/10.1002/ 2013RG000443

Harvey RW (1997) Microorganisms as tracers in groundwater injection and recovery experiments: a review. FEMS Microbiol Rev 20:461472

Hodel H, Stoller F (2000) Technischer Bericht, Messkampagne mit den Lichtleiter-Fluorometern LLF-1 und LLF-M, Feldmessungen, Erfahrungen, Ausblick und offene Fragen [Technical report, measurement campaign with fiber-optic fluorometers LLF-1 and LLF$\mathrm{M}$, field measurements, experiences, outlook and open questions]. BAFU, Bern, Switzerland

Hofstraat JW, Steedijk M, Vriezekolk G, Schreurs W, Broer GJAA, Wijnstok N (1991) Determination of rhodamine WT in surface water by solid-phase extraction and HPLC with fluorescence detection. Water Res 25(7):883-890

Hossain MA, Canning J, Ast S, Rutledge PJ (2014) Lab-in-a-phone: smartphone-based portable fluorometer for $\mathrm{pH}$ measurements of environmental water. IEEE Sensors J 15(9):5095-5102

Hötzl H, Käss W, Reichert B (1991) Application of microbial tracers in groundwater studies. Water Sci Technol 24:295-300

Ikeyaa T, Horimoto N, Kashino Y (2009) A practical method for sensitive determination of the fluorescent water-tracer uranine by reversed phase HPLC under alkaline conditions. Talanta 79:818-823

ISO 9555-3 International Standard (1992a) Measurement of liquid flow in open channels: tracer dilution methods for the measurement of steady flow - part 3: chemical tracers. ISO, Geneva

ISO 9555-4 International Standard (1992b) Measurement of liquid flow in open channels: tracer dilution methods for the measurement of steady flow_ part 4: fluorescent tracers. ISO, Geneva

IUPAC (International Union of Pure and Applied Chemistry) (2016) Atomic weights of the elements 2013 (IUPAC technical report). Pure Appl Chem 88(3):265-291

Jones WK (1984) Analysis and interpretation of data from tracer tests in karst areas. NSS Bull 1984(Oct):41-47

Kasnavia T, De V, Sabatini DA (1999) Fluorescent dye and media properties affecting sorption and tracer selection. Ground Water 37(3): 376-381

Käss W (1964) Die unmittelbare Bestimmung von Uranin-Spuren bei Färbversuchen [The direct determination of traces of uranine in dye tests]. Steir Beitr z Hydrogeol 15(16):37-74

Käss W (1982) Fluoreszierende Sporen als Markierungsmittel [Fluorescent spores as tracer]. Beitr Geol Schweiz 29(I):131-134

Käss W (1998) Tracing technique in geohydrology. Balkema

Käss W (2004) Geohydrologische Markierungstechnik [Geohydrologic tracing technique], 2nd edn. Lehrbuch der Hydrogeologie, Bd 9, Borntraeger

Käss W, Reichert B (1988) Tracing of karst water with fluorescent spores. In: Morfis A, Papadimitropoulos P (eds) Proc. 5th Int. Symp. Underground Water Tracing (SUWT), Athens, Greece, p 157-165

Kemp L, Jamieson EC, Gaskin SJ (2010) Phosphorescent tracer particles for Lagrangian flow measurement and particle tracking velocimetry. Exp Fluids 48:927-931 
Kendall C, McDonnell JJ (eds) (2006) Isotope tracers in catchment hydrology. Elsevier

Kennedy K, Niehren S, Rossi P, Schnegg P-A, Müller I, Kinzelbach W (2001) Results of bacteriophage, microsphere and solute tracer migration: comparison at Wilerwald testfield, Switzerland. In: Tracer studies in the unsaturated zone and groundwater (investigations 1996-2001), 8th Int. Symp. on water tracing, Munich 2001. Beitr Hydrogeol 52:180-210

Keswick BH, Wang DS, Gerba CP (1982) The use of microorganisms as ground-water tracers: a review. Ground Water 20:142-149

Knop A (1878) Über die hydrographischen Beziehungen zwischen der Donau und der Aachquelle im badischen Oberlande [About hydrographic relationships between the Danube and Aach Spring in the uplands of Baden]. N Jb Mineral 1878:350-363

Kogovsek J, Petric M (2014) Solute transport processes in a karst vadose zone characterised by long-term tracer tests [The cave system of Postojnska Jama, Slovenia]. J Hydrol 519:1205-1213

Kovács A, Sauter M (2007) Modelling karst hydrodynamics. In: Goldscheider N, Drew D (eds) Methods in karst hydrogeology. Int Contrib Hydrogeol 26:201-222

Kreft A, Zuber A (1978) On the physical meaning of the dispersion equation and its solutions for different initial and boundary conditions. Chem Eng Sci 33(11):1471-1480

Kreft A, Lenda A, Turek B, Zuber A, Czauderna K (1974) Determination of effective porosities by the two-well pulse method. In: Isotope techniques in groundwater hydrology, vol 2. IAEA, Vienna, $p$ 295-312

Kresic N, Stevanovic Z (2009) Groundwater hydrology of springs. Butterworth-Heinemann

Kübeck C, Maloszewski P, Benischke R (2012) Determination of the conduit structure in a karst aquifer based on tracer data: Lurbach system, Austria. Hydrol Process 27(2):225-235. https://doi.org/10. 1002/hyp.9221

Laane RWPM, Manuels MW, Staal W (1984) A procedure for enriching and cleaning up rhodamine B and rhodamine WT in natural waters, using a SEP-PAK C18 cartridge. Water Res 18:163-165

Lallemand A, Paloc H (1964) Possibilités offertes par la méthode de détection au charbon actif pour les expériences de coloration a la fluorescéine [Possibilities of the detection method with activated charcoal in tracer tests with fluorescein]. Actes VIe Congrès National de Spéléologie, Spelunca, Mémoires 4, Valencia, Spain, May 1964, p 27-40

Launay M, Tripier M, Guizerix J, Viriot ML, Andre JC (1980) Pyranine used as a fluorescent tracer in hydrology: $\mathrm{pH}$ effects in determination of its concentration. J Hydrol 46(3-4):377-383

Leibundgut C, Hadi S (1997) A contribution to toxicity of fluorescent tracers. In: Kranjc A (ed) Tracer Hydrology 97, Proc 7th Int Symp Water Tracing, Portoroz, Slovenia, 26-31 May 1997, Balkema, p 69-75

Leibundgut C, Seibert J (2011) Tracer Hydrology. In: Wilderer P (ed) Treatise on water science, vol 2. Academic Press, p 215-236

Leibundgut C, Wernli HR (1986) Naphthionate: another fluorescent dye. In: Morfis A, Paraskevopoulou P (eds) Proc. 5th Int. Symp. on underground water tracing, Athens, Greece, September 1986, p $167-177$

Leibundgut C, Maloszewski P, Külls C (2009) Tracers in hydrology. Wiley-Blackwell

Leis A, Benischke R (2004) Comparison of different stable hydrogen isotope-ratio measurement techniques for tracer studies with deuterated water in the unsaturated zone in groundwater. In: 7th Workshop of European Society for Isotope Research (ESIR VII), Seggauberg, Austria, 27 June-1 July 2004, Berichte d. Inst. f. Erdwissenschaften, Karl-Franzens-Universität Graz, 8:85-87

Leis A, Schmitt R, Van Pelt A, Plieschnegger M, Harum T, Zerobin W, Stadler H (2010) On-site measurement of stable environmental isotopes at karst springs with high time-resolution and on-line data availability. Proc. 10th Stable Isotope Network Austria (SINA) Meeting, Seibersdorf, Austria, 25-26 Nov. 2010, p 7-8

Leis A, Schmitt R, Van Pelt A, Plieschnegger M, Stadler H (2011) Isotope investigations at an alpine karst aquifer by means of onsite measurements with high time resolution and near real-time data availability. IAEA Int. Symp. on Isotopes in Hydrology, Marine Ecosystems, and Climate Change Studies, Monaco, 27 March-1 April 2011, IAEA-CN-186131, IAEA, Vienna, p 145-152

Lenda A, Zuber A (1970) Tracer dispersion in groundwater experiments. In: Isotope hydrology 1970. IAEA, Vienna, p 619-641

Liao R, Yang P, Wu W, Luo D, Yang D (2018) A DNA tracer system for hydrological environment investigations. Environ Sci Technol 52(4):1695-1703

Licha T, Niedbala A, Bozau E, Geyer T (2013) An assessment of selected properties of the fluorescent tracer Tinopal CBS-X related to conservative behaviour and suggested improvements. J Hydrol 484:3844

Lichacz R (1987) A review of the literature on the toxicology of fluorescent dye. Australian Caver 113:13-15

Little LW, Lamb JC (1973) Acute toxicity of 46 selected dyes to fathead minnow (Pimephales promelas). In: Dyes and the environment: reports on selected dyes and their effects, vol 1. American Dye Manufacturers Inst., New York, p 1-26

Lloyd JBF (1971) Synchronized excitation of fluorescence emission spectra. Nature Phys Sci 231:64-65

Luhmann AJ, Covington MD, Alexander SC, Chai SY, Schwartz BF, Groten JT, Alexander EC Jr (2012) Comparing conservative and nonconservative tracers in karst and using them to estimate flow path geometry. J Hydrol 448-449:201-211

Lutty GA (1978) The acute intravenous toxicity of biological stains, dyes and other fluorescence substances. Toxicol Appl Pharmacol 44: 225-249

Maloszewski P, Zuber A (1985) On the theory of tracer experiments in fissured rocks with a porous matrix. J Hydrol 79:333-358

Maloszewski P, Harum T, Benischke R (1992) Mathematical modelling of tracer experiments in the karst of the Lurbach system. In: Behrens H, Benischke R, Bricelj M, Harum T, Käss W, Kosi G, Leditzky H, Leibundgut C, Maloszewski P, Maurin V, Rajner V, Rank D, Reichert B, Stadler H, Stichler W, Trimborn P, Zojer H, Zupan M (1992) Investigations with natural and artificial tracers in the karst aquifer of the Lurbach system (Peggau - Tanneben - Semriach, Austria). Steir Beitr z Hydrogeol 43:116-143

Maloszewski P, Benischke R, Harum T, Zojer H (1994) Estimation of solute transport parameters in heterogeneous groundwater systems of a karstic aquifer using artificial tracer experiments. Water Down Under '94, part A, vol 2, Adelaide, Australia, November 1994, p $105-111$

Marking LL (1969) Toxicity of rhodamine B and fluorescein sodium to fish and their compatibility with antimycin A. Progress FishCulturist 31:139-142

Maurin V, Zoetl J (1967) Salt water encroachment in the low altitude karst water horizons of the island of Kephallinia (Ionian Islands). IAHS Proc. Symposium "Hydrology of fractured rocks", Dubrovnik, Croatia, Oct. 1965, p 423-438

Mayr A (1953) Blütenpollen und pflanzliche Sporen als Mittel zur Untersuchung von Quellen und Karstwässern [Flower pollen and plant-based spores as means for the investigation of spring and karst waters]. Anz. Oesterr. Akad. Wiss., Math.-naturwiss. K1. 90:94-98

Mayr A (1954) Hydrogeologische Studien im Dachsteingebiet [Hydrogeological studies in the Dachstein region]. Mitt. Höhlenkommission b. Bundesministerium f. Land- u. Forstwirtschaft, 1953(1):90-96

Meus P, Schnegg P-A, Frippiat C, Monfort J (2014) Promises and limitations in the use of sulfonates colourless tracers in hydrogeology. Geol Belg 17(1):90-95 
Milanovic PT (1976) The review of exploration of karst underground water flow in Popovo polje, Yugoslavia, Paper 3rd Int. Symp. Underground Water Tracing (3rd SUWT), Ljubljana, Slovenia, $p$ $157-167$

Milanovic PT (2018) Karst hydrogeology. Reprint, Water Resources Publ.

Mitoff D (1944) Potentiometrische Messungen an Karst- und anderen Wässern [Potentiometric measurements at karst waters and other waters]. Abh. d. Reichsamtes f. Bodenforschung 209:337-344

Molinari J, Rochat J (1978) Synthèse bibliographie Sur la toxicité des substances fluorescentes utilisées en hydrologie [Bibliography of toxicity of fluorescent substances in hydrology]. Int J Speleol 10: 269-277

Mook WG ed (2000) Enivironmental isotopes in the hydrological cycle: principles and applications, vol 6. IAEA, Vienna

Moser H, Rauert W (1980) Isotopenmethoden in der Hydrologie [Isotope methods in hydrology]. Lehrbuch d Hydrogeologie, vol 8, Borntraeger, Stuttgart, Germany

Moulin C, Vitart X (1998) Pulsed microchip laser induced fluorescence for in situ tracer experiments. Fresenius J Anal Chem 361:81-85

Mudarra M, Andreo B, Barbera JA, Mudry J (2014) Hydrochemical dynamics of TOC and NO3-contents as natural tracers of infiltration in karst aquifers. Environ Earth Sci 71:507-523

Mull DS, Liebermann TD, Smoot JL, Woosley LH Jr (1988) Application of dye-tracing techniques for determining solute-transport characteristics of ground water in karst terranes. EPA 904/6-88-001, US EPA, Washington, DC

Müller I, Zötl J (1980) Karsthydrologische Untersuchungen mit natürlichen und künstlichen Tracern im Neuenburger Jura (Schweiz) [Karsthydrogeologic investigations with natural and artificial tracers in the Neuenburg Jura - Switzerland]. Steir Beitr z Hydrogeol 32:5-100

NCBI (2020) PubChem. National Center for Biotechnology Information. https://pubchem.ncbi.nlm.nih.gov. Accessed December 2020

Niehren S, Kinzelbach W (1998) Artificial colloid tracer tests: development of a compact on-line microsphere counter and application to soil column experiments. J Contam Hydrol 35:249-259

OeWAV (ed) (2007) Markierungsversuche in der Hydrogeologie [Tracer tests in hydrogeology]. OeWAV-Regelblatt 214, Österr. Wasserund Abfallwirtschaftsverband (OeWAV), Vienna

Palmer AN (2007) Cave geology. Cave Books

Parriaux A, Liszkey M, Müller I, Della Valle G (1988) Leitfaden für den Gebrauch künstlicher Tracer in der Hydrogeologie [Guideline on the use of artificial tracers in hydrogeology]. Schweizerische Geol. Ges. (Swiss Geol. Soc.), Bern, Switzerland

Perlega W (1976) Der Nachweis von Fluoreszenzfarbstoffen mittels Aktivkohle [Detection of fluorescent dyes with activated carbon]. Paper 3rd Int. Symp. Groundwater Tracing (SUWT), Ljubljana, Slovenia, 1976, p 195-201

Poulain A, Rochez G, Van Roy J-P, Dewaide L, Hallet V, De Sadelaer G (2017) A compact field fluorometer and its application to dye tracing in environments. Hydrogeol J 25:1517-1524

Pronk M, Goldscheider N, Zopfi J (2006) Dynamics and interaction of organic carbon, turbidity and bacteria in a karst aquifer system. Hydrogeol J 14(4):473-484

Pronk M, Goldscheider N, Zopfi J, Zwahlen F (2009) Percolation and particle transport in the unsaturated zone of a karst aquifer. Ground Water 47(3):361-369

Quinlan JF (1986a) Discussion of "Ground-water tracers" by Davis et al. (1985), with emphasis on dye-tracing, especially in karst terranes. Ground Water 24(2):253-259

Quinlan JF (1986b) Discussion of "Ground-water tracers" by Davis et al. (1985), with emphasis on dye-tracing, especially in karst terranes. Ground Water 24(3):396-397
Reid GC (1981) Literature evaluation of induced groundwater tracers, field tracer techniques, and hydrodynamic dispersion values in porous media. MSc Thesis, Texas Tech. University, Lubbock, TX

Reischer GH, Haider JM, Sommer R, Stadler H, Keiblinger KM, Hornek R, Mach RL, Zerobin W, Farnleitner AH (2008) Quantitative microbial faecal source tracking with sampling guided by hydrological catchment dynamics. Environ Microbiol 10:2598-2608

Richter G (1944) Zur Kennzeichnung unterirdisch fließender Wässer. Untersuchungen an der Range und anderen Karstquellen bei Warstein (Westfalen) [On the labelling of subterranean waters. Investigations at the Range and other karst springs in Westphalia]. Abh. d. Reichsamtes f. Bodenforschung 209:299-336

Rochat J, Alary J, Molinari J, Charrierre R (1975) Séparations physicochimiques de colorants xanthéniques utilisés comme traceurs [Physico-chemical separations of xanthenic dyes used as tracers]. J Hydrol 26:277-293

Rossi P, Doerfliger N, Kennedy K, Müller I, Aragno M (1998) Bacteriophages as surface and ground water tracers. Hydrol Earth Syst Sci 2(1):101-110

Rumble JR, Lide DR, Bruno TJ (2019) CRC handbook of chemistry and physics: a ready-reference book of chemical and physical data, 100th edn. CRC, Boca Raton, FL

Ryzinska-Paier G, Lendenfeld T, Correa K, Stadler P, Blaschke AP, Mach RL, Stadler H, Kirschner AKT, Farnleitner AH (2014) A sensitive and robust method for automated on-line monitoring of enzymatic activities in water and water resources. Water Sci Technol 69:1349-1358

Sabir IH, Haldorsen S, Torgersen J, Aleström P, Gaut S, Colleuille H, Pedersen TS, Kitterod N (2000) Synthetic DNA tracers: examples of their application in water related studies. In: Dassargues A (ed) Tracers and modelling in hydrogeology, Proc. TraM'2000 Conf, Liege, Belgium, May 2000, IAHS-Publ 262:159-165

Sabnis RW (2015) Handbook of fluorescent dyes and probes. Wiley, Hoboken, NJ

Schiperski F, Zirlewagen J, Scheytt T (2016) Transport and attenuation of particles of different density and surface charge: a karst aquifer field study. Environ Sci Technol 50:8028-8035

Schiperski F, Oertwich M, Scheytt T, Licha T (2019) Solubility of Tinopal CBS-X fluorescent dye at different EDTA concentrations and $\mathrm{pH}$ values: implications regarding its applicability in field tracer tests. J Hydrol 578:124025

Schnegg P-A (2002) An inexpensive field fluorometer for hydrogeological tracer tests with three tracers and turbidity measurement. In: Bocanegra E, Martinez D, Massone H (eds), Proc XXXII IAH and ALHSUD Congress Groundwater and Human Development, Mar del Plata, Argentina, 20-25 October 2002, Balkema, p 1484-1488

Schnegg P-A (2008) Field fluorometers for the hydrogeology. Improved separation of uranine from other dye tracers using laser light. Poster, AGU Fall Meeting, San Francisco, 15-19 Dec. 2008

Schnegg P-A, Doerfliger N (1997) An inexpensive flow-through field fluorometer. Proc. 12th Int. Congress of Speleology, vol 2, La Chaux-de-Fonds, Switzerland, 10-17 August 1997, p 47-50

Schubert G (2017) Karstwasser Dachstein [Karst Water Dachstein]. Arbeitstagung Geol Bundesanstalt 2017:86-93

Schudel B, Biaggi D, Dervey T, Kozel R, Müller I, Ross JH, Schindler U (2002) Einsatz künstlicher Tracer in der Hydrogeologie: Praxishilfe [Application of artificial tracers in hydrogeology: practical assistance]. Ber. d. BWG, Serie Geologie, no. 3, BAFU, Bern, Switzerland

Seidlitz HK, Behrens H (1991) Verbesserung der Nachweisempfindlichkeit von Fluoreszenztracern [Enhancement of the detection sensitivity of fluorescent tracers]. Jahresber 1990, GSF-Inst. f. Hydrologie, Munich, Germany, p 141-144

Si W, Hongyan M, Prytkova I, Stenoien DD, Pasa-Tolic L (2017) The encyclopedia of spectroscopy and spectrometry, 3rd edn. Elsevier, Amsterdam 
Smart CC (1988) Artificial tracer techniques for the determination of the structure of conduit aquifers. Ground Water 26(4):445-453

Smart CC (2005) Error and technique in fluorescent dye tracing. 10th Multidisciplinary Conf. on Sinkholes and the Engineering and Environmental Impacts of Karst, ASCE Geotechn. Special Publ. https://doi.org/10.1061/40796(177)53

Smart CC, Karunaratne KC (2002) Characterization of fluorescence background in dye tracing. Environ Geol 42:492-498

Smart CC, Simpson B (2002) Detection of fluorescent compounds in the environment using granular activated charcoal detectors. Environ Geol 42:538-545

Smart CC, Worthington SRH (2004) Groundwater in karst: Borehole hydrology. In: Gunn (ed) Encyclopedia of caves and karst science. Fitzroy Dearborn, p 397-398

Smart CC, Zabo L, Alexander EC Jr, Worthington SRH (1998) Some advances in fluorometric techniques for water tracing. Environ Monit Assess 53:305-320

Smart PL (1984) A review of the toxicity of twelve fluorescent dyes used for water tracing. NSS-Bull 46:21-33

Smart PL, Laidlaw IMS (1977) An evaluation of some fluorescent dyes for water tracing. Water Res Res 13:15-33

Smart PL, Smith DI (1976) Water tracing in tropical regions, the use of fluorometric techniques in Jamaica. J Hydrol 30:179-195

Smith SA, Pretorius WA (2002) The conservative behaviour of fluorescein. Water SA 28(4):403-406

Stadler H, Skritek P (2001) Remote data transmission for hydrological investigations: state-of-the-art and further trends. In: Mudry J, Zwahlen F (eds) Proc. 7th Conf. on Limestone Hydrology and Fissured Media, Besançon, France, 20-22 Sept 2001, p 319-323

Stadler H, Skritek P, Pindeus D, Zerobin W, Farnleitner AH (2010) Datenakquisition in der Hydrologie: Anwendungen in der Erkundung und Überwachung von Trinkwasserressourcen [Hydrological data acquisition: applications in exploration and surveillance of drinking water resources]. Beitr Hydrogeol 57:103-128

Stöckl L, Pechstein A, Margane A (2017) Practice guide for tracer tests in groundwater. Tech. Rep. no. III-3, July 2017, BGR, Hanover, Germany

Suijlen JM, Staal W, Houpt PM, Draaier A (1994) A HPLC-based detection method for fluorescent seawater tracers using on-line solid phase extraction. Cont Shelf Res 14:1523-1538

Sutton DJ, Kabala ZJ, Vasudevan D (2000) Rhodamine WT as a reactive tracer: laboratory study and field consequences. In: Dassargues (ed) Tracers and modelling in hydrogeology. Proc. TraM'2000, Liege, Belgium, May 2000, IAHS Publ 262:201-205

Tang G, Mayes MA, Parker JC, Jardine PM (2010) CXTFIT/Excel: a modular adaptable code for parameter estimation, sensitivity analysis and uncertainty analysis for lab and field tracer experiments. Comput Geosci 36(9):1200-1209. https://doi.org/10.1016/j.cageo. 2010.01.013

Toride N, Leij FJ, Van Genuchten MT (1999) The CXTFIT code for estimating transport parameters from laboratory or field tracer experiments. Res. Rep. no. 137, US Salinity Laboratory, USDA, ARS, Riverside, CA

Turnadge C, Smerdon BD (2014) A review of methods for modelling environmental tracers in groundwater: advantages of tracer concentration simulation. J Hydrol 519:3674-3689
Upstill-Goddard RC (2001) The use of photolytic rhodamines WT and sulpho $\mathrm{G}$ as conservative tracers of dispersion in surface waters. Limnol Oceanogr 46(4):927-934

Viriot ML, André JC (1988) Fluorescent dyes: a search for new tracers for hydrology. Analusis 17(3):97-111

Völkl G, Eybl J (2019) Künstliche und natürliche Markierungen des Karstwassers am Beispiel des Dachsteinmassivs [Artificial and natural tracing of karst water by the example of the Dachstein massif]. Österr Wasser Abfallwirtschaft 71:51-65

Ward RE, Williams AT, Barker JA, Brewerton LJ, Gale IN (1998) Groundwater tracer tests: a review and guidelines for their use in British aquifers. British Geol. Surv. Techn. Rep. WD/98/19 Hydrogeology Series (R\&D Tech. Rep. W160), BGS, Keyworth, UK

Weiss S, Müller A, Albert R, Schulz W, Weber WH (2008) Identifizierung von Farbstoff-Tracern und deren Metaboliten nach HPTLC/AMD und Nano-Chip-LC/QTOF-MS [Identification of dye tracers and their metabolites with HPTLC/AMD and Nano-Chip-LC/QTOF-MS]. Poster, Zweckverband Landeswasserversorgung, Stuttgart, Germany

Werner A (1998) Hydraulische Charakterisierung von Karstsystemen mit künstlichen Tracern ([Hydraulic characterisation of karst systems with artificial tracers]. Schriftenreihe Angew Geol Karlsruhe, Universität Karlsruhe, Germany

Werner A (2004) TRACI: ein mathematisches Interpretationsmodell für Markierungsversuche [TRACI: a mathematical model for interpretation of tracer tests]. In: Käss W (ed) Geohydrologische Markierungstechnik, Borntraeger, p 322-329

Wernli HR (1986) Naphthionat: ein neuer Fluoreszenztracer zur Wassermarkierung [Naphthionate: a new fluorescent tracer for water labelling]. Deutsche Gewässerkdl Mitt 30(1):16-19

Wilson JF, Cobb ED, Kilpatrick FA (1986) Fluorometric procedures for dye tracing. USGS Techniques of Water Resources Investigations, book 3, Application of hydraulics, $34 \mathrm{p}$

Wolkersdorfer C, LeBlanc J (2012) Regulations, legislation, and guidelines for artificial surface water and groundwater tracer tests in Canada. Water Qual Res J Can 47(1):42-55

Worthington SRH, Smart CC (2003) Empirical determination of tracer mass for sink to spring tests in karst. In: Beck BF (ed) Sinkholes and the engineering and environmental impacts on karst. Geotech. Spec. Publ. no. 122, ASCE, Reston, VA, p 287-295

Yang Y, Lowry M, Xu X, Escobedo JO, Sibrian-Vazquez M, Wong L, Schowalter CM, Jensen TJ, Fronczek FR, Warner IM, Strongin RM (2008) Semi-naphthofluorones are a family of water-soluble, low molecular weight, NIR-emitting fluorophores. PNAS 105(26): $8829-8834$

Zötl JG (1957a) Der Einzugsbereich von Quellen im Karstgebirge [The catchment area of springs in a karst massif]. Österr Wasserwirtschaft 9(4):77-86

Zötl JG (1957b) Neue Ergebnisse der Karsthydrologie [New results in karst hydrology]. Erdkunde 9:107-117

Zötl JG (1974) Karsthydrogeologie [Karst hydrogeology]. Springer

Publisher's note Springer Nature remains neutral with regard to jurisdictional claims in published maps and institutional affiliations. 